\title{
A heritage stone of Rio de Janeiro (Brazil): the Facoidal gneiss
}

Nuria Fernández Castro, M.Sc., Graduate Program in Geology - Federal University of Rio de Janeiro - PPGL/UFRJ; Centre for Mineral Technology - Ministry of Science, Technology and Innovation - CETEM/MCTI, Rio de Janeiro, RJ BRAZIL; *Corresponding author, E-mail: ncastro @cetem.gov.br;nutriacastro@gmail.com

(Received: February 20, 2020; Revised accepted: December 10, 2020)

https://doi.org/10.18814/epiiugs/2020/0200s13

This paper presents the Facoidal gneiss, the most significant and characteristic natural and heritage stone of Rio de Janeiro, Brazil, also known as 'the most carioca of rocks.' The metropolis that is a World Heritage Cultural Landscape was built on, over, around, and with local stones, mostly Neoproterozoic gneisses. Among them, Facoidal gneiss occurs both sides of the Guanabara Bay, shaping its natural monuments as the Corcovado and the Sugar Loaf. It is composed of K-feldspar megacrysts usually deformed, looking like eyes (augen), arranged in a quartzfeldspar and biotite rich matrix. Its colour varies from pink to greyish. This stone was substantially used as a building material in many heritage monuments and buildings, in frames of windows and doors in houses, in sidewalks and public infrastructures. The aggressive environment of Rio de Janeiro, a tropical coastal megalopolis, is reflected in decay patterns such as loss of matrix and spalling. There are no quarries in production as this rock outcrops stand inside nature conservation or urbanized areas. The current impossibility of extracting replacement material justifies calling attention to this stone for the better conservation of Rio de Janeiro's built heritage.

\section{Introduction: Facoidal Gneiss Heritage Aspects}

Rio de Janeiro, also called just 'Rio', was inscribed as World Heritage Cultural Landscape in 2012 by the United Nations Educational, Scientific and Cultural Organization - UNESCO, under the title: 'Rio de Janeiro: Carioca Landscapes between the Mountain and the Sea' as a recognition of the exceptional value of the intrinsic relationship between landscape and society according to criteria ' $\mathrm{v}$ ' - creative fusion between nature and culture, based on scientific, environmental and design ideas - and 'vi' - the inspiration for many forms of arts and worldwide recognition of a staggering beauty (UNESCO, 2012). Carioca is the Portuguese demonym for the city of Rio de Janeiro.

This city has also been declared, by UNESCO and the International Union of Architects, as the first World Capital of Architecture in 2020, because of its 'reputation for its architecture, urban design, cultural heritage, physical beauty and historical significance' (Vonier, 2019).

Nature, culture, and history are so imbricated that they cannot be separated. Rio de Janeiro's rocks had a significant role in its history and, consequently, in its heritage as they not only shape the relief but also have influenced its urban development (Mansur et al., 2008a). On one side, the landscape of hills surrounded by swamps and lagoons represented a challenge for the inhabitants to settle and expand the city as the population grew. On the other side, the stones extracted from those hills served as building material to perform that problematic task.

The peaks, hills, and mountains of Rio's landscape are composed mainly of gneisses and granites. From the numerous varieties of igneous and metamorphic local rocks, three stand out as historical building materials in Rio de Janeiro, all of them known by their lithotype's old names in Portuguese: a porphyroclastic biotite gneiss that is known as 'Facoidal' (the Portuguese word for augen gneiss and used here as that rock's proper noun), a garnet-bearing leucocratic gneiss called 'Leptinito' and, to a lesser degree, a kinzigitic gneiss, called 'Kinzigito' (Fig. 1).

Facoidal gneiss is the most representative lithotype of the coastal massifs of the Guanabara Bay (Silva et al., 2003; Valeriano et al., 2012). The famous hills of the city, such as the Sugar Loaf and the Corcovado (Fig. 2) owe their current form to that gneiss' higher resistance to weathering than the surrounding rocks (Mansur, 2008b; Fernandes et al., 2010). This rock is 'at sight' both as natural and as constructed geoheritage, according to the interpretation of De Wever et al. (2017).

The peaks and hills are the result of important stages of the Earth's history geological processes, the Gondwana formation during the Neoproterozoic and the South Atlantic aperture during the Mesozoic. The Sugar Loaf Natural Monument was recognized as a significant world's geological site, representative of the Gondwana amalgamation, by the International Union of Geological Sciences - IUGS during the 31st International Geological Congress that took place in Rio, in 2000 (Silva and Ramos, 2002).

Many visitors have described Rio's mountains in texts, pictures, and engravings since the 16th century. In the 19th century, scientific expeditions with naturalists and geologists from several countries, such as Luccock (1820), Spix and Martius (1824), Gardner (1849), Hartt (1870, travelling with Agassiz) made descriptions of those bedrocks. Caldcleugh (1825) described the 'geological formation round the bay 


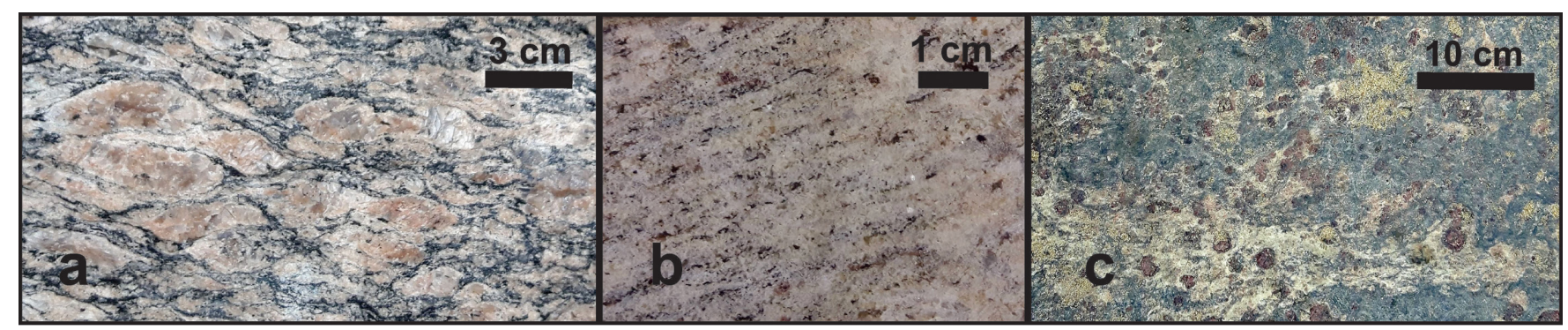

Figure 1. Main aspect of Facoidal (a), Leptinito (b), and Kinzigito (c) gneisses. Photos by the authors.

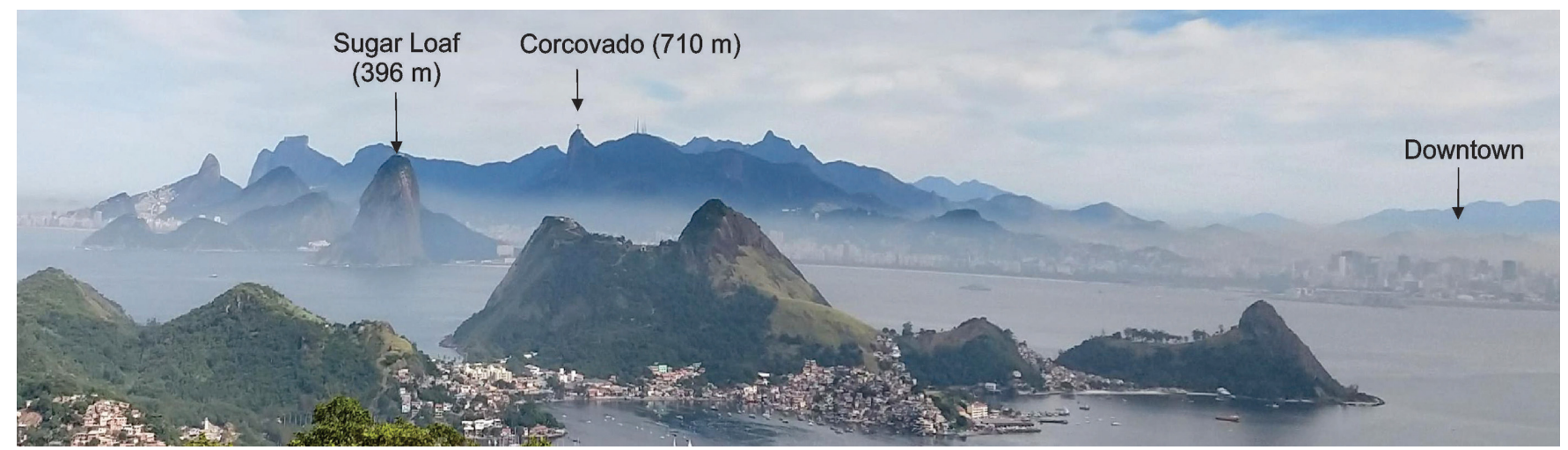

Figure 2. View of the Guanabara Bay from the City Park in Niterói. Photo by Elaine Turatto, 2019. Used with permission.

[...] essentially composed of gneiss of various kinds, frequently of a porphyritic structure, intersected by granite veins and full of garnets' after presenting rocks samples and his observations on the geology of Rio de Janeiro to the Geological Society of London in 1823 (GSL, 1829). Darwin (1846) also made a detailed and accurate description of the rocks of Corcovado and Sugar Loaf mountains. A hand sample and a thin-section of Facoidal gneiss from his collection are exposed at the Sedgwick Earth's Sciences Museum (https://www.virtualmicroscope.org/content/garnet-biotite-augen-gneiss). Rossiter Worthington Raymond and James Furman Kempf also described this rock in 1895 and 1896, respectively (Porto Jr. and Duarte, 2012).

Facoidal gneiss occurs in the South and Central regions of Rio stretching northeast across the Guanabara Bay for $30 \mathrm{~km}$. The abundance of this rock close to the urban area fostered its extensive use in monuments, buildings, and public works from the 16th to the 20th century. It ornaments many houses' doors and windows frames - an inherited Portuguese use - and integrates monumental buildings and artistic monuments from the end of the 19th and beginning of the 20th century. This period corresponds to the birth of Brazilian architecture when Facoidal gneiss uses become more artistical, composing façades and sculpted ornaments in buildings, fountains, and monuments (Morales de los Ríos, 1911).

This gneiss is also the main component of the World Heritage Archaeological Site of the Valongo Wharf (UNESCO, 2017), the most significant African slave's port of the American continent. Close to it, in the same region, called 'Little Africa', an outcrop of Facoidal gneiss has become a symbol of the Brazilian-African culture and accepted as the place where the samba and the carnival were born. The State of Rio de Janeiro registered it as a cultural and religious heritage site in 1987 (INEPAC, 2020). Several samba schools have highlighted that stone and reproduced its texture in allegorical floats representing the cari- oca's way of life, and the city's buildings and monuments in the carnival parade. Today even a musical group in Rio de Janeiro is named after that stone: 'Banda do Gnaisse' (Gneiss Band). All this together makes the Facoidal gneiss merit the title of 'the most carioca of rocks' (Mansur et al., 2008a).

This paper presents Facoidal gneiss characteristics, historical uses, sources, and durability issues, aiming to improve the visibility of this heritage stone of Brazil. It also intends to contribute to the goals of the IUGS Heritage Stones Subcommission of disseminating knowledge about natural stones of importance for the human culture worldwide (Hughes et al., 2013; Pereira et al., 2014, 2015; Freire-Lista et al., 2015) and to the HerStones project that focusses on heritage stones of emerging countries and is supported by the UNESCO's International Geosciences Program - IGCP.

\section{Geological Framework}

The Guanabara Bay, where the city of Rio de Janeiro is located, belongs to the Mantiqueira Province, one of the structural provinces of Brazil and a complex orogenic system that extends along 3,000 km of the Brazilian coast (Fig. 3).

The Guanabara Bay is inserted in the Central Ribeira Belt (Heilbron et al., 2016). This very complex belt was formed by lithospheric compressive events resulting in the West Gondwana Paleocontinent amalgamation, known as the Pan African/Brazilian orogeny (Fig. 4).

This process that involved subduction, collision, and the collapse of the orogen, between $790 \mathrm{Ma}$ and $480 \mathrm{Ma}$ (Tupinambá et al., 2012; Heilbron et al., 2016; Schmitt et al., 2018), is considered one of the most comprehensive examples of the Precambrian diachronic orogenic history (Heilbron et al., 2020). During these continental colli- 


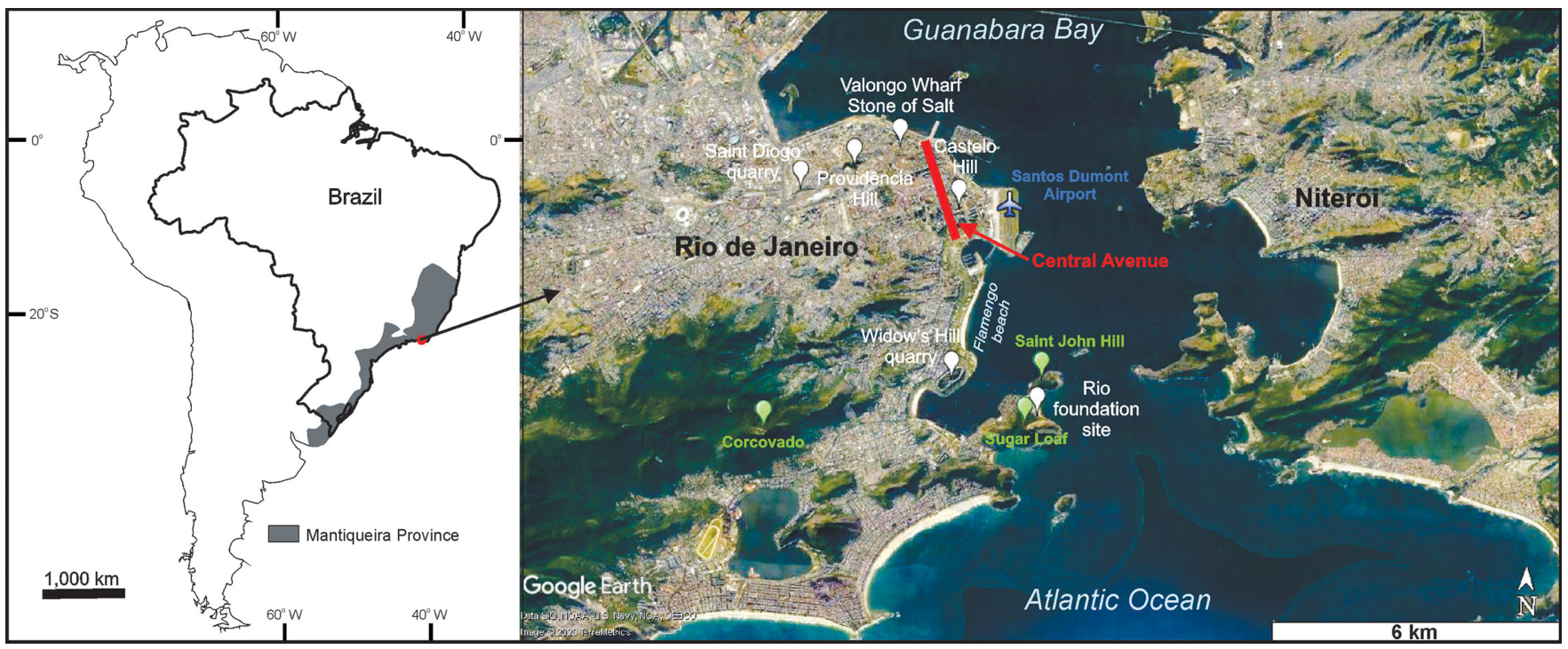

Figure 3. Location map of the Guanabara Bay within the Mantiqueira Province in Brazil, and some places mentioned in the text. Sources: IBGE (2020), Hasui et al. (2012) and Google Earth Pro (2020).

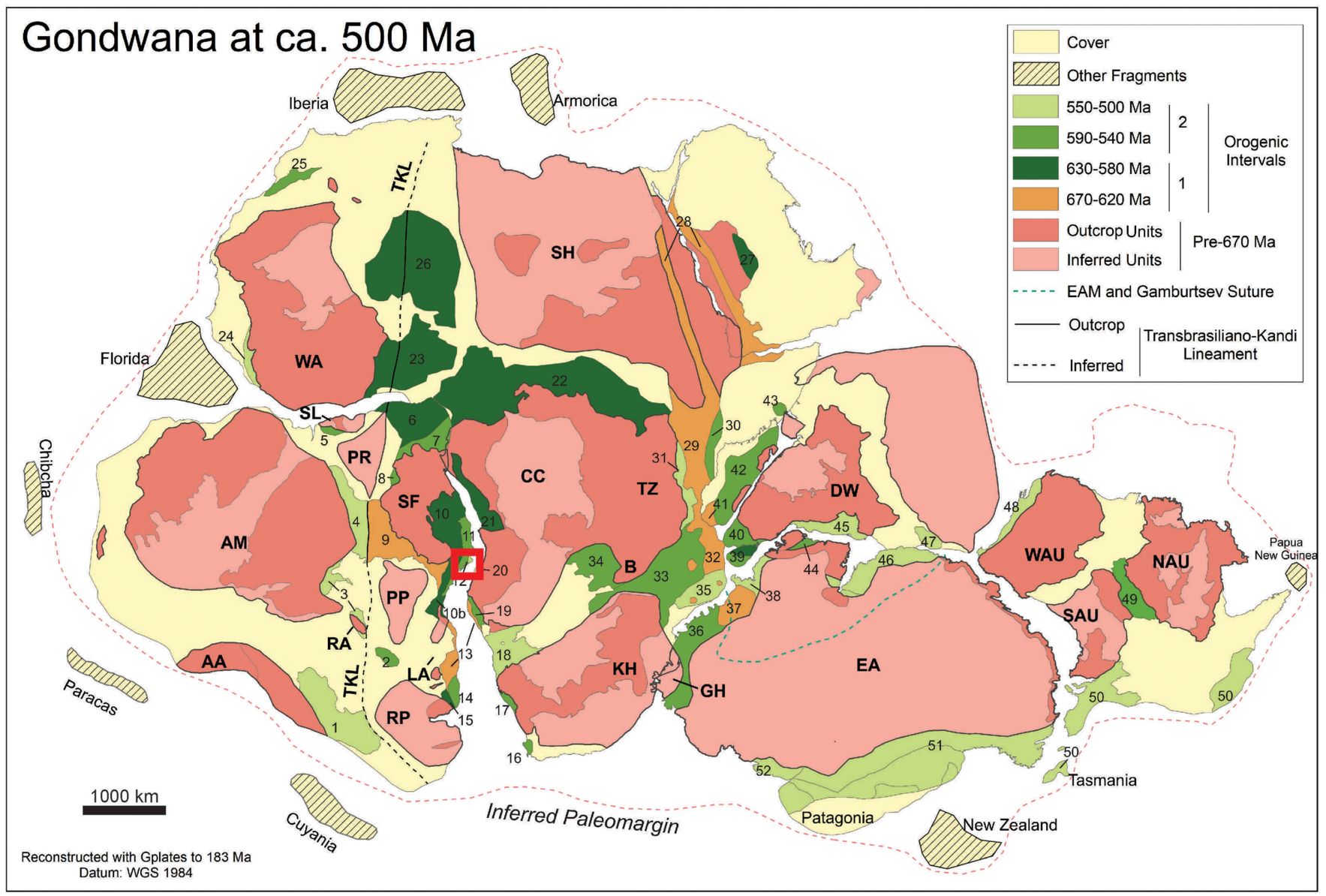

Figure 4. Gondwana configuration showing the location of the Guanabara Bay (red), Rio de Janeiro, Brazil. Abbreviations represent Gondwanan cratons: AA Arequipa/Antofalla; AM Amazonia; RA Río Apa; SL São Luís; PR, Parnaíba; SF, São Francisco; PP, Paranapanema; LA Luís Alves; RP Río de La Plata; KH, Kalahari; B Bangweulu Block; TZ Tanzania; CC Congo; WA West Africa; SH Sahara; DW Dharwar; GH Grunehogna; EA East Antarctica; WAU West Australia; SAU South Australia; NAU North Australia. Numbers represent Gondwanan mobile belts. Number 11-Araçuaí (East), Ribeira (Oriental Terrane) and Costeiro Domain. TKL stands for TransbrasilianoKandi Lineament. Image by Schmitt et al., 2018. Used with permission. 
sion events, migmatites, ortho and paragneisses, and granitic rocks were formed, including those that are found in the coastal area of Rio de Janeiro. Facoidal gneiss, whose origin is related to the melting and subsequent metamorphism of colliding continental crusts rocks, is the most representative of them (Silva et al., 2003). Radiometric ages for the Facoidal batholith emplace it at the main tectono-metamorphic event (590-550 Ma), more specifically at the peak of the low angle compressive tectonism coincident with the beginning of metamorphism, around $560 \mathrm{Ma}$ (U-Pb-Th SHRIMP, 50 analyses in 42 zircon crystals, by Silva, 2003). It occurs both sides of the bay, in an area of around $200 \mathrm{~km}^{2}$ (Hippert, 1990).

After stabilization and relatively calm geological timeframe, the rock massifs were exposed due to the break-up of the Gondwana supercontinent and aperture of the South Atlantic Ocean, during the Juro-Cretaceous period (130 Ma). This stage is represented on the continent rocks by the intrusion of tholeiitic dykes swarms. Lastly, about $60 \mathrm{Ma}$, faults were reactivated, and the Guanabara Graben was formed, in between two mountain chains running parallel to the coast, the Serra do Mar (to the West) and Serra da Carioca (to the East), uplifting the impressive mountains and peaks that still today conform the bay and vicinities landscape. The higher resistance of Facoidal gneiss to weathering causes it to occur in the most prominent portions of the city's relief. Sediments covered the graben during the Cenozoic, including the anthropogenic landfills from the 16th to the 20th centuries (Silva et al., 2015).

The complex tectonic and geomorphological history has resulted in a wide variety of lithologies in the State of Rio de Janeiro and a spectacular landscape for the Guanabara Bay (Fig. 5).

\section{Facoidal Gneiss Characteristics}

\section{Names}

Facoidal gneiss (Backheuser, 1925) is the preferential and most known designation of this rock. Geological texts also have referred to it as Porphyritic gneiss (Darwin, 1846), Lenticular gneiss (Lamego, 1964), Augen gneiss (Hippert, 1990) or adopted toponymic names such as Pão de Açúcar (Sugar Loaf) granite and Corcovado granite (Silva, 2001). In architectural and historical texts, though, the more familiar names are Carioca granite (Rio's granite, Morales de los Rios Filho, 1941), Pedra da terra (local stone, Telles, 2007) and Pedra de galho (twig stone, Freitas, 1878). The last one was the term used by the stoneworkers (Latif, 1942).

\section{Petrographic Description}

Facoidal gneiss is orthoderivated (syeno- to monzogranitic), lightcoloured (varying from pinkish grey to yellowish-red) and coarsegrained, displaying K-feldspar, and minor plagioclase, as megacrysts ( 2 to $15 \mathrm{~cm}$ ) that usually constitute isoriented pinkish or whitish lenses, or augens, in a biotite rich quartz-feldspar (plagioclase) matrix. Ribbons of quartz and garnet clusters are frequent. Its texture varies from well deformed, almond-shaped (Fig. 6b) to idiomorphic rectangular feldspar crystals. (Fig. 6a). Cross-cut faces of a block may appear significantly different than the vein-cut ones, sometimes showing a globular texture.

The main composition is K-feldspar (+microcline) $(35 \%)$, quartz $(30 \%)$, plagioclase $(20 \%)$, and biotite $(10 \%)$. It may contain garnet, muscovite, and other accessory minerals including hornblende, zircon, apatite, magnetite and ilmenite. Microcline can constitute more than 50\% in samples with larger crystals (Fig. 6b).

\section{Chemical Composition}

The mean chemical composition of 15 samples from Rio de Janeiro and 17 from Niterói (Retamal, 2013) is shown in Table 1.

\section{Technological Properties}

Facoidal gneiss is no longer commercialized, thus the only available data about its technological properties are a few published in

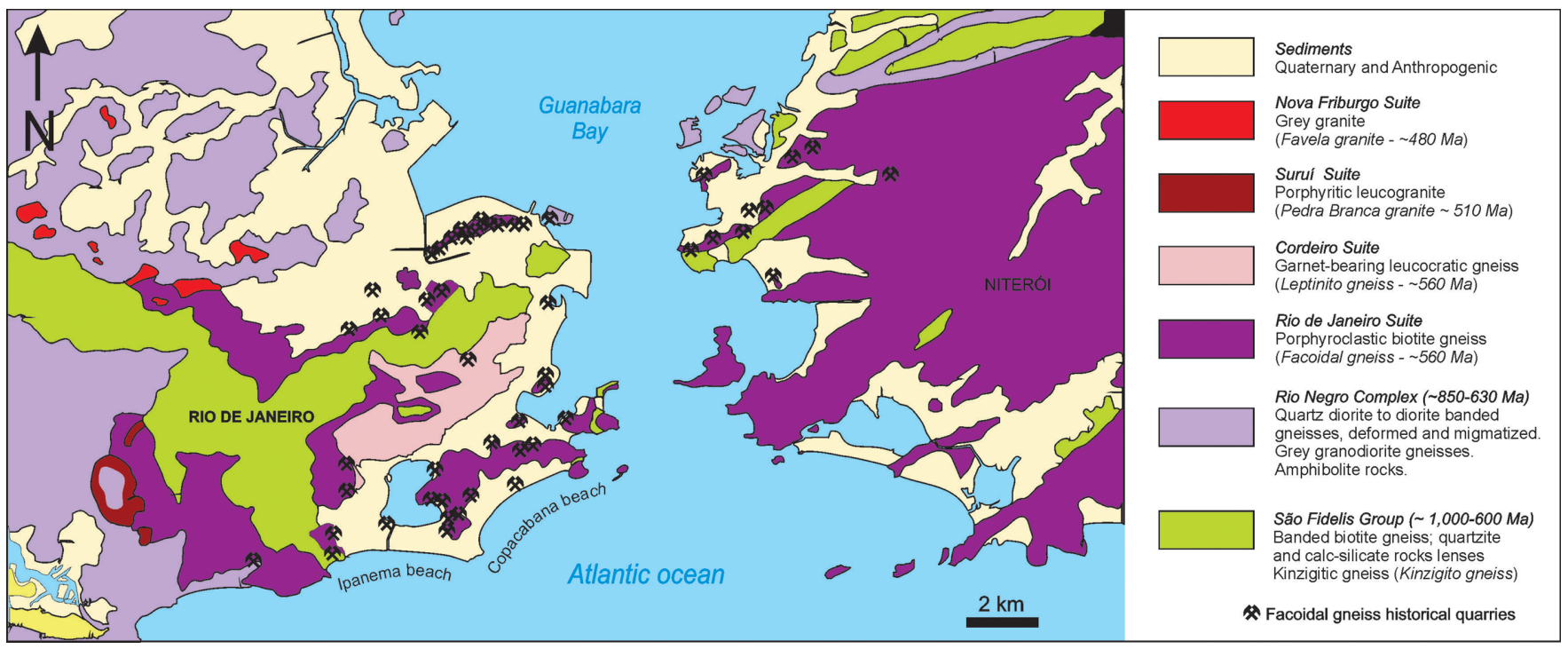

Figure 5. Simplified lithological map of the mouth of the Guanabara Bay, at 1: 100,000 scale with location of historical Facoidal gneiss quarries. Sources: Reis (1934), Silva (1936), and Almeida and Almeida (2012), Almeida and Porto (2012), Valeriano et al. (2012), and CPRM (2020). 


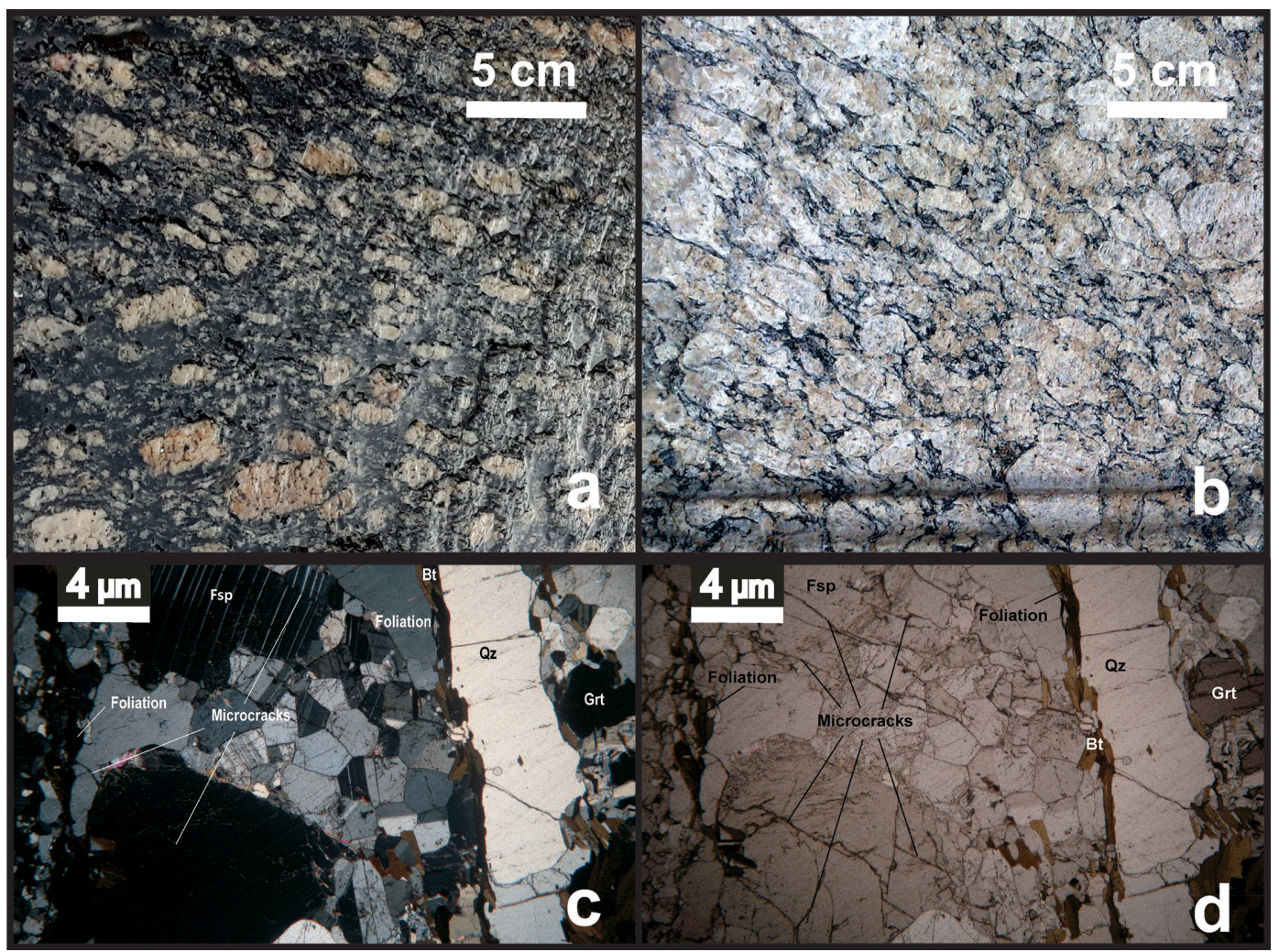

Figure 6. (a) and (b) Textural variation as a function of minerals content and deformation. (c) and (d) photomicrographs of a thin section of Facoidal gneiss, showing a quartz ribbon ( $Q z$ z), feldspar (Fsp) as megacryst and matrix, biotite (Bt), and garnet (Grt) in cross-polarized light (c) and plane-polarized light (d). Images by the authors.

Table 1. Mean chemical composition of Facoidal gneiss. Source: Retamal, 2013

\begin{tabular}{cccccccccccccc}
\hline \hline & \multicolumn{10}{c}{ Chemical composition (weight percent) } \\
\hline & $\mathrm{SiO}_{2}$ & $\mathrm{CaO}$ & $\mathrm{Fe}_{2} \mathrm{O}_{3}$ & $\mathrm{~K}_{2} \mathrm{O}$ & $\mathrm{MgO}$ & $\mathrm{Na}_{2} \mathrm{O}$ & $\mathrm{P}_{2} \mathrm{O}_{5}$ & $\mathrm{Al}_{2} \mathrm{O}_{3}$ & $\mathrm{TiO}_{2}$ & $\mathrm{MnO}$ & $\mathrm{LOI}$ \\
\hline \%wt. & 70,71 & 2,17 & 2,97 & 5,03 & 0,82 & 3,35 & 0,18 & 13,72 & 0,54 & 0,05 & 0,66 \\
$\mathrm{SD}^{\text {(a) }}$ & 1,58 & 0,41 & 0,94 & 0,47 & 0,31 & 0,44 & 0,06 & 0,38 & 0,20 & 0,01 & 0,21 \\
\hline
\end{tabular}

(a) standard deviation

Table 2. Technological characteristics of Facoidal gneiss (compiled from Del Vecchio, 1884; Silva, 1936; Marques et al., 2010; Ricardo, 2015; Ricardo et al., 2017; Gimenez, 2018)

\begin{tabular}{|c|c|c|c|}
\hline \multicolumn{3}{|c|}{ Technological characteristics } & Author \\
\hline \multirow[t]{2}{*}{ Density } & \multicolumn{2}{|c|}{$2,692 \mathrm{~kg} / \mathrm{m}^{3}$} & Gimenez, 2018 \\
\hline & \multicolumn{2}{|c|}{$2,690 \mathrm{~kg} / \mathrm{m}^{3}$} & Del Vecchio, 1884 \\
\hline Water Absorption & \multicolumn{2}{|c|}{$0.26 \%$} & Gimenez, 2018 \\
\hline Apparent porosity & \multicolumn{2}{|c|}{$0.71 \%$} & Gimenez, 2018 \\
\hline Open Porosity & \multicolumn{2}{|c|}{$0.98 \%$} & Ricardo, 2015 \\
\hline Sound speed propagation & \multicolumn{2}{|c|}{$4,530 \mathrm{~m} / \mathrm{s}$} & Ricardo et al., 2017 \\
\hline \multirow[t]{2}{*}{ Compressive strength } & $71.4 \mathrm{MPa}^{(\mathrm{a})}$ & $62.3 \mathrm{MPa}^{(\mathrm{b})}$ & Silva, 1936 \\
\hline & $77.9 \mathrm{MPa}^{(\mathrm{a})}$ & $74.1 \mathrm{MPa}^{(\mathrm{b})}$ & Marques et al., 2010 \\
\hline Tensile strength & \multicolumn{2}{|c|}{$3.92 \mathrm{MPa}$} & Del Vecchio, 1884 \\
\hline Point load strength index (IS-50) & 2.46 & 2.49 & Marques et al., 2010 \\
\hline Schmidt hardness strength & $15.1 \mathrm{MPa}^{(\mathrm{a})}$ & $15.9 \mathrm{MPa}^{(\mathrm{b})}$ & Gimenez, 2018 \\
\hline
\end{tabular}

(a) perpendicular to foliation; ${ }^{(b)}$ parallel to foliation

journals in the 19th-20th centuries (Del Vecchio, 1884; Silva, 1936) and some from recent scientific researches (Marques et al., 2010; Ricardo,
2015; Ricardo et al., 2017a; Gimenez, 2018) that are summarized in Table 2. 


\section{Facoidal Gneiss Uses through History}

Rio de Janeiro was 'discovered' on the 1st of January of 1502, by a Portuguese expedition that gave the place its current name, which means January's River - it is believed they mistook the bay with two arms of a river. It was not until 1565, however, after expelling French invaders who had occupied the Guanabara Bay, that the city of Saint Sebastian of Rio de Janeiro was officially founded in between the Sugar Loaf Mountain and Saint John Hill (Fig. 3). Those mountains, mostly composed of Facoidal gneiss, offered initial protection to the settlers (Fernandes et al., 2010). In 1567, the city was transferred to the Castelo Hill - demolished in the 1920s and today a flat area close to the Santos Dumont airport (Fig. 3) - from where Rio de Janeiro's urbanization began (Abreu, 2010). Though the human occupation of South America extends to, at least, 13,000 BC (Lopes, 2017) and around 20 different tribes had lived in the Guanabara Bay until the 16th century (Edelweiss, 1967), there are no records of natives using stones as building materials in the manner other native Pre-Columbian cultures did. The first use of Facoidal gneiss as a building material was a house erected in 1531 at the current Flamengo Beach (Cavalcanti, 2004). Nevertheless, during the first century of Portuguese occupation, the preferred building materials were clay and timber; the number of houses built with stone and lime only started to grow from the middle of the 17th century onwards, being dominant at the end of that century (Abreu, 2010).

Due to its higher hardness and difficulty of being worked than the Leptinito gneiss, the most used for stonework in the colonial period (1500 - 1815), Facoidal gneiss served mostly as landfill material or civil works elements such as water pipes, bridges and rough blocks for harbour docks, while in buildings it composed rubble masonry walls and cornerstones, sills, and jambs following the Portuguese style (Freitas, 1878). It also served to pave the streets with the typical style known as pé-de-moleque (peanut brittle), which consists of placing irregular stones right over the soil or sand. In the 18th century, according to Gonçalves (2004), started the production of big flat, squared paving stones, with Facoidal gneiss of the Saint Diogo quarry (Fig. 3). Several neighbourhoods of the city exhibit those stones. Fig. 7 illustrates some of the aforementioned uses of Facoidal gneiss.

The exceptions were several fortresses for the defence of the city, such as Holy Cross (1555) and Saint John (1565), both sides of the Guanabara Bay, erected with Facoidal gneiss masonry, as they stood on that lithotype outcrops.

The first artistic stone works of Facoidal gneiss date from the end of the colonial period: a wall and a portal at the Public Promenade (1785), the Fountain of XV square (1789) and the Holy Cross of Military Church façade (1780-1811), the first Neoclassic of Brazil, combining Facoidal gneiss in structural elements with mouldings and sculptures of Lioz Limestone from Portugal (Fig. 8). All of them had the hand of one of the most important Brazilian artists, Master Valentim (Lúcio Costa, 1984 apud Alves, 2011).

In 1808 the King of Portugal, his family and court, moved to Rio de Janeiro, which was no more than a village then, lacking housing to accommodate such a large contingent of people. Many reforms were promoted to improve the colonial city to become the capital of the Kingdom (1815 - 1822) opening communication roads, increasing the habitable ground by landfilling existent marshes and lagoons between

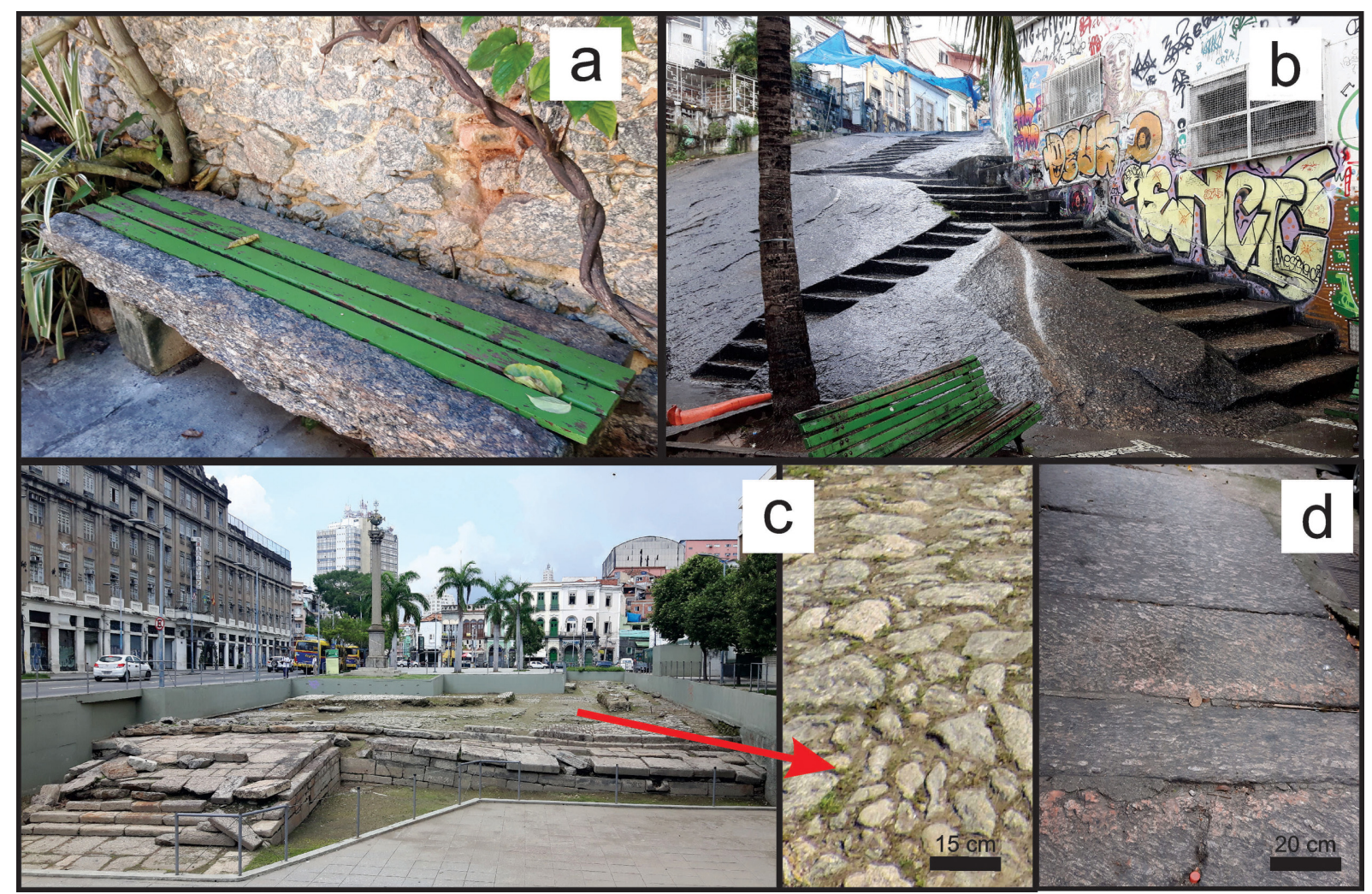

Figure 7. Traditional uses of Facoidal gneiss as a rough construction material: (a) water pipe (bench) and rubble stone wall, (b) carved stair of the Stone of Salt monument, (c) ramp and quay of the archaeological site of the Valongo Wharf (detail pé-de-moleque pavement), (d) old squared flagstones. Photos by the authors. 


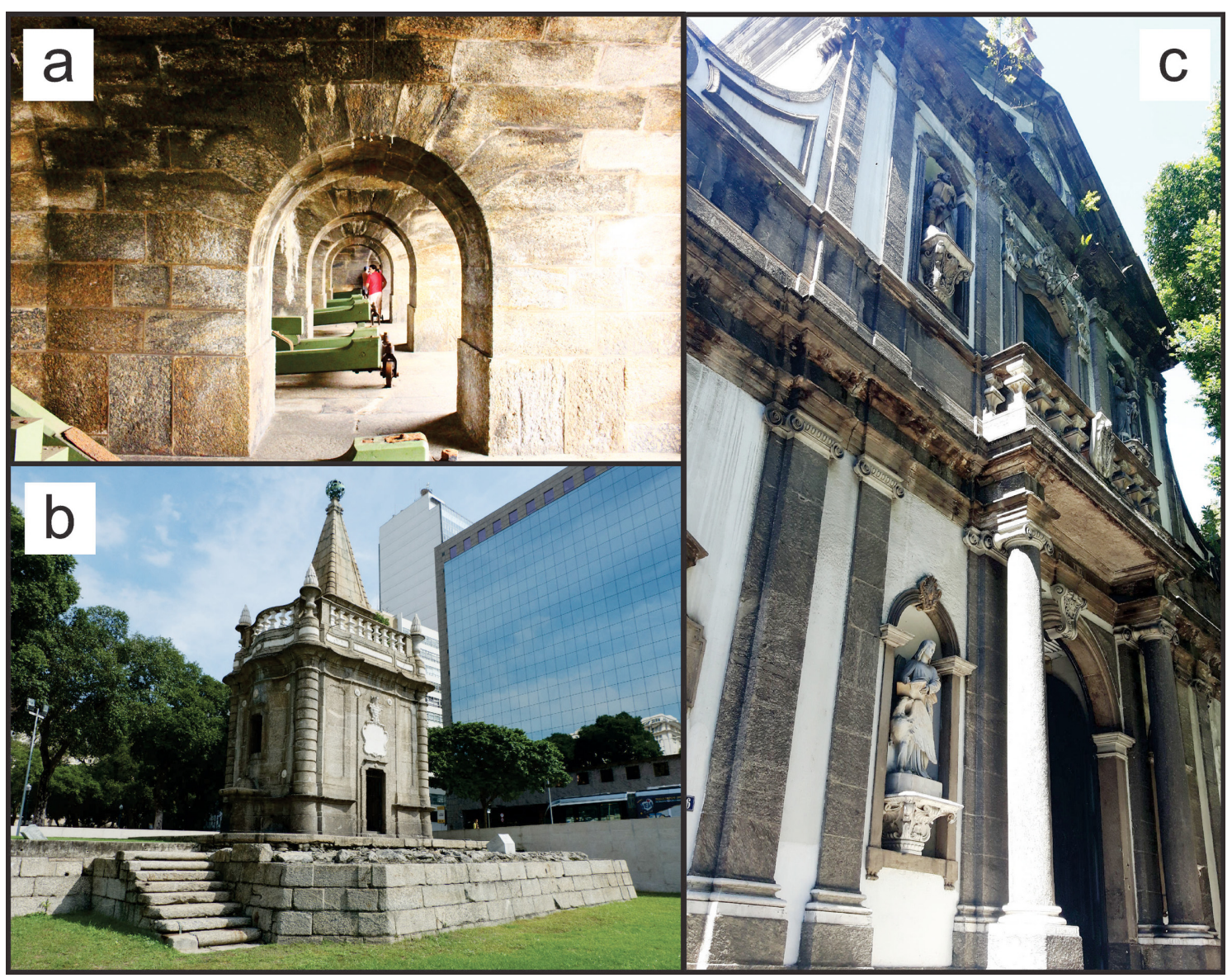

Figure 8. Some uses of Facoidal gneiss in the colonial period (1500-1815): (a) canons gallery of the Holy Cross Fortress. Photo by Filipo Tardim, 2014. Wikimedia Commons, CC BY-SA 4.0, (b) Master Valentim's Fountain. Photo by Daniel Barbutti, 2017. Wikimedia Commons, CC BY-SA 4.0, (c) Holy Cross of Military Church façade. Photo by the authors.

the mountains, and extending the coastline over the sea. From then until now this has been a constant for Rio de Janeiro. It has suffered many and massive urbanistic reforms throughout its history, most of them for sanitary reasons and aiming to the city embellishment in a European way, in order to achieve the status of a modern South Amer- ican metropolis (Abreu, 2010). Those reforms increased Facoidal gneiss use, despite eliminating most of the first possible buildings or monuments made with it. The building codes of the 19th century explicitly stated the use of stonework in doors and windows frames (arcs, jambs, and sills) as well as on the sidewalk's pavements (Brasil, 1838, 1855,
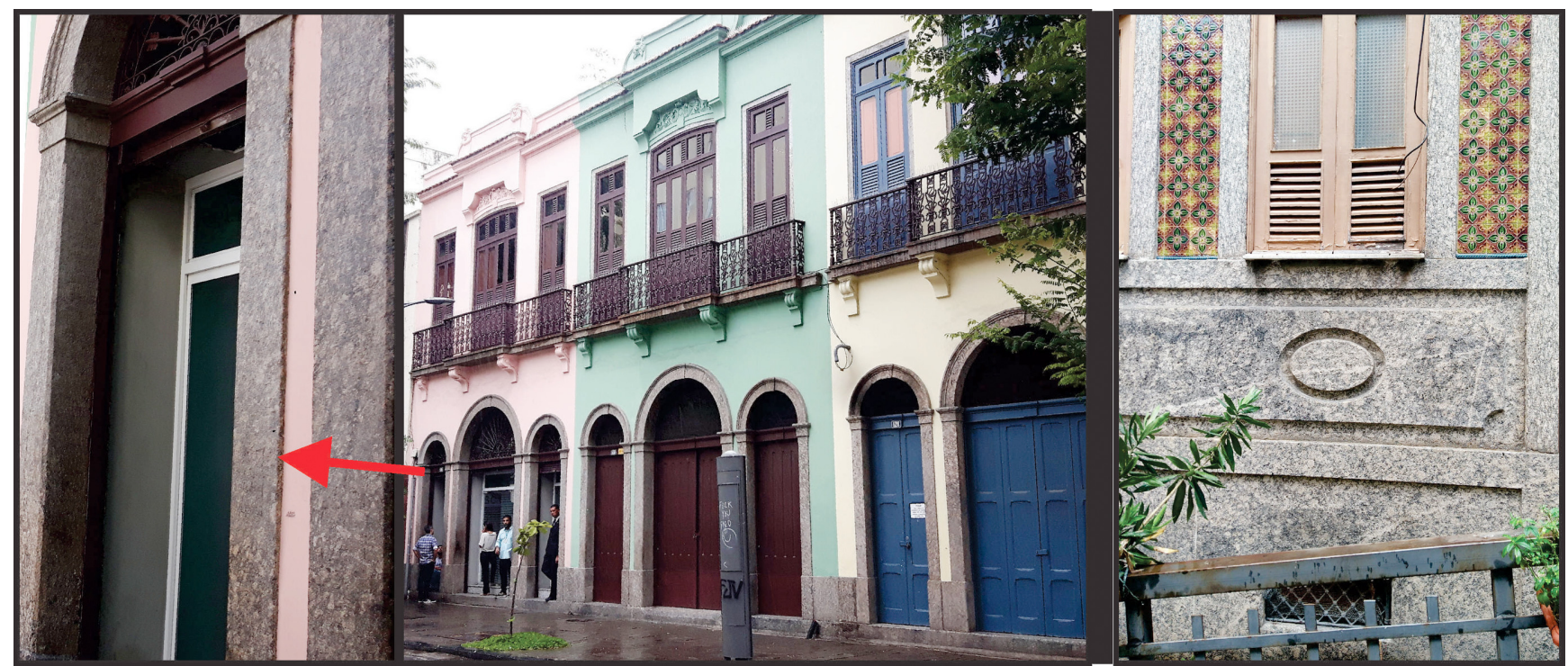

Figure 9. Typical Facoidal gneiss uses as façades ornaments in houses. Photos by the authors. 
1893). Therefore, Facoidal gneiss can be seen in many streets and private buildings today (Fig. 9).

The importance of this gneiss grew enormously in the second half of the 19th century, particularly after the end of the imperial period (1822 - 1889) with the proclamation of the republic (Andrade, 2016). A Brazilian nationalism was starting to flourish, and there was a need to show the world that Brazilians were civilized and had their own artistic and architectural expressions independent of the rigid and considered unaesthetic patterns of the Portuguese style adapted to the colony. The use of local building materials was privileged over the imported ones, and Facoidal gneiss, the 'hard granite of beautiful sight' became the main component of façades and ornaments. Its use was driven by the French architect Grandjean de Montigny and followed by his disciples at the end of the 19th and beginning of the 20th century (Morales de los Ríos, 1911). They had the support of Antônio Jannuzzi, owner with his brother of the Jannuzzi Brothers Building Company, and the Widow's Hill quarry (Fig. 3). According to Bell (1914) He apparently delights into work the rough Carioca granite in enormous blocks' and built over 5,000 buildings. Most of the monumental constructions uplifted in this period with Facoidal gneiss are National Heritage (Fig. 10).

The beginning of the 20th century kept this pace of monumentality and profusion of Facoidal gneiss façades. In 1905, the construction of a long and wide elegant avenue downtown (Central Avenue, current Rio Branco Avenue, see, Fig. 3) led to the demolition of almost 600 old buildings and houses, which were replaced afterwards by huge buildings: the Municipal Theatre, the Fine Arts Museum, and many others. The area close to the Sugar Loaf was urbanized, and also there edifices were built using Facoidal gneiss, such as the Earth Sciences Museum (Fig. 11). Further massive demolitions followed in the last century, but concrete substituted the stone in the new buildings. The population growth and the urbanistic reforms forced the closure of the quarries (Reis, 1934). The last new construction that made use of Facoidal gneiss was the Capanema Palace (1937), the first modernist project of the country, developed by a team of talented Brazilian architects under the supervision of Le Corbusier (Ribeiro, 2011). Burle Marx, responsible for many built landscapes in Rio the Janeiro, recycled Facoidal gneiss pieces in most of his works and used them to ornament his house and tropical garden. This house, already National Heritage, was included in the World Heritage Tentative List in 2015 (O Globo, 2019). Examples of Facoidal gneiss uses in the 20th century are illustrated in Fig. 11. Table 3 presents some of the built heritage sites of the Guanabara Bay, where Facoidal gneiss can be seen today.

Facoidal gneiss is present in many other heritage sites and monuments not listed above and, undoubtedly, there are more to discover yet. Historically, the graphical documentation on buildings and monuments has been preferred over the textual one (Andrade, 2016). Even today, building stones are not usually identified in Brazil or, at best, they are recorded just like granite or gneiss.

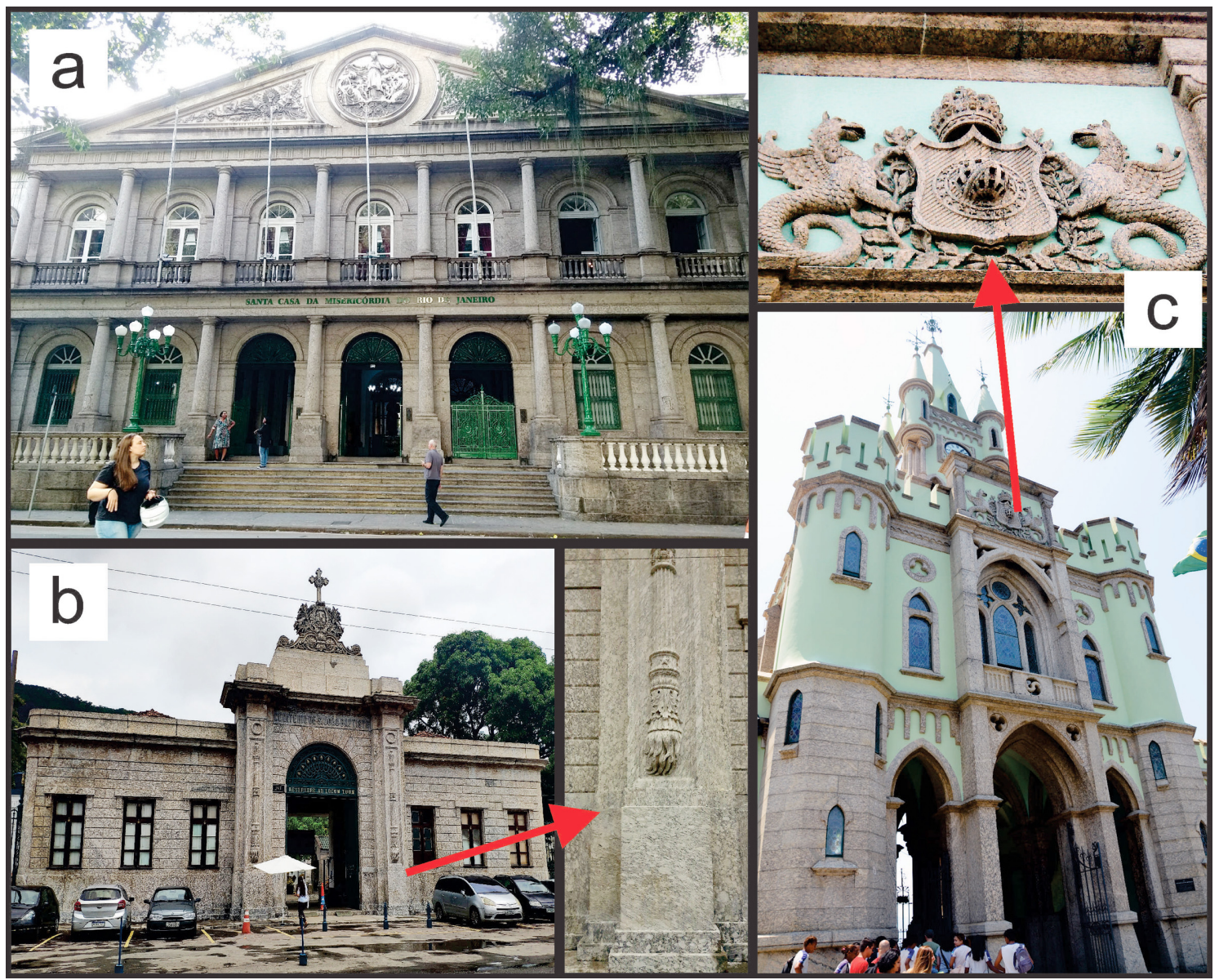

Figure 10. Facoidal gneiss monuments of the 19th century: (a) Saint House of Mercy Hospital. Photo by the authors, (b) Saint John the Baptist Cemetery Portal and detail. Photo by the authors, (c) Ilha Fiscal Palace entrance. Photo by Rodrigo Soldon, 2011, CC BY-ND 2.0, and detail of the imperial coat-of-arms carved in Facoidal gneiss. Photo by Jonas de Carvalho, 2005, CC BY-ND 2.0. 


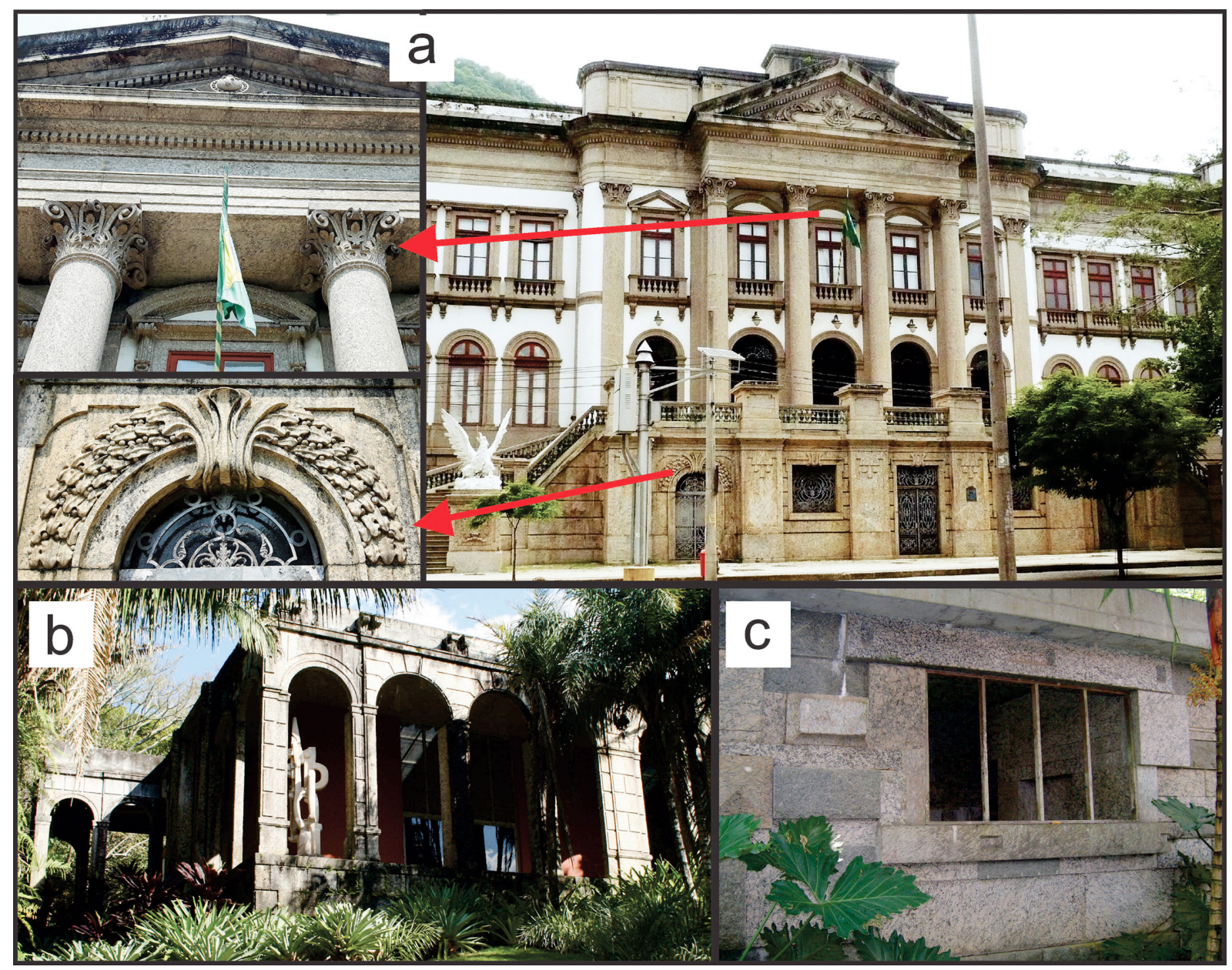

Figure 11. Facoidal gneiss monuments of the 20th century: (a) Earth's Science Museum (photo by Carlos Luis M C da Cruz, 2009, Wikimedia Commons, Public domain), and details (photos by the authors), (b) Burle Marx's house structure with Facoidal demolition material (photo by Halley Pacheco de Oliveira, 2009, Wikimedia Commons, CC BY-SA 3.0), (c) Wall at Burle Marx's house, where all the ashlars but the dark grey ones are of Facoidal gneiss (Photo by the authors).

Rio de Janeiro's stones were used in surrounding cities and also in other states and neighbouring countries (Sá, 1886). Several advertisements of stone suppliers in the 19th century offered Facoidal gneiss to be dispatched to the provinces and to serve as ballast stone, having some of them their own docks to embark it (Almanak Laemmert, 1857, 1859, 1875; Revista dos Construtores, 1886). For example, Facoidal gneiss is the base of a statue dedicated to Tiradentes (meaning 'tooth puller', the head of a revolt against the Portuguese, in the 18th century) in Ouro Preto, Minas Gerais - this city is also a World Heritage Site (Fig. 12a). Rio's gneisses were transported by the Borders Demarcation Commission to set the Brazilian borders landmarks (Jardim, 2000; Potoko, 2013). The landmark on the Trindade Island, the eastern geographic point of Brazil, made of Facoidal gneiss, is known as the 'sovereignty monument' (Fig. 12b) after winning over England a territorial dispute on that island (Brazil, 2017). Examples of Facoidal gneiss used outside of Rio are given in Table 4.

Facoidal gneiss, probably together with other lithotypes, travelled to different continents too as ships' ballast stone (United States, 1880). Hence, they may have served to pave the streets or built foundations in their destination countries, as noticed by Hall (1890) during the construction of houses foundation-walls in Barnstaple (UK). The stones were erroneously believed to originate from the Lundy Island but turned out to have become from a ship ballast from Rio de Janeiro. Another interesting example is the stone edging of Facoidal gneiss at the Botanic Gardens of Brisbane, in Australia (von Gnielinski and Siemon, 2012; Swan, 2018).

\section{Quarries}

The source quarries were all the hills and mountains with Facoidal gneiss outcrops, in the cities of Rio de Janeiro, Niterói, and São Gonçalo, on the other side of the Guanabara Bay (Lamego, 1964). The map in Fig. 5 shows the location of historical quarries both sides of the bay, based on Almeida and Porto (2012) and complemented with data from Reis (1934), Silva (1936) and Almeida and Almeida (2012).

African slaves quarried the stone and, after the slavery abolition, also did immigrants (Almeida, 2016). The workers manually drilled, blasted and cut the stone by plugs and feathers (wedges and shims), observing the fracture planes of the large feldspar crystals (Revista dos Construtores, 1886). Several travellers, such as Mawe (1812), Spix and Martius (1824), and Burmeister (1853) described that slow and 
Table 3. Some heritage monuments built with Facoidal gneiss in Rio and Niterói

\begin{tabular}{|c|c|c|c|}
\hline \multirow{2}{*}{ Name } & \multirow{2}{*}{ Date of construction } & \multicolumn{2}{|c|}{ Geographical Coordinates (WGS84) } \\
\hline & & Latitude & Longitude \\
\hline Holy Cross Fortress & 1555 & -22.937868 & -43.134097 \\
\hline Saint John Fort & 1565 & -22.943316 & -43.157115 \\
\hline Chapel of Our Lady of Drop Head & 1602 & -22.960963 & -43.220896 \\
\hline Our Lady of Conception Fortress & 1711 & -22.898717 & -43.183265 \\
\hline Monastery of Saint Benedict & 1742 & -22.897044 & -43.177995 \\
\hline Imperial Palace & 1743 & -22.903700 & -43.174361 \\
\hline Saint Luzia Church & 1752 & -22.909614 & -43.172528 \\
\hline Saint Louis Fortress & 1769 & -22.936460 & -43.122428 \\
\hline Portal of Villegaignon's Fort & 1775 & -22.913194 & -43.159375 \\
\hline Church of Our Lady of the Candelaria & 1775 & -22.900883 & -43.177853 \\
\hline Holy Cross of the Military Church & 1780 & -22.902218 & -43.175762 \\
\hline Master Valentim Fountain & 1789 & -22.902679 & -43.173853 \\
\hline Saracuras Fountain & 1795 & -22.985168 & -43.197797 \\
\hline Valongo Wharf & 1811 & -22.896695 & -43.187202 \\
\hline Hospital of the Saint House of Mercy & 1840 & -22.907681 & -43.170841 \\
\hline University Palace of the Federal University of Rio de Janeiro & 1842 & -22.952293 & -43.174445 \\
\hline Grandjean de Montigny Fountain & 1850 & -22.961223 & -43.273390 \\
\hline Saint John Baptist Cemetery & 1852 & -22.957364 & -43.189159 \\
\hline São John Baptist Church & 1864 & -22.954013 & -43.191364 \\
\hline Catete Palace & 1867 & -22.925829 & -43.176179 \\
\hline Saint Francis of Assisi Hospital & ca. 1870 & -22.908976 & -43.201419 \\
\hline Benjamin Constant Institute & 1872 & -22.953454 & -43.172228 \\
\hline Post Central Agency & 1876 & -22.901645 & -43.175983 \\
\hline Bank of Brazil Cultural Center & 1880 & -22.900830 & -43.176450 \\
\hline Ilha Fiscal Palace & 1881 & -22.896911 & -43.166371 \\
\hline Cultural Centre of the Electoral Justice & 1892 & -22.902050 & -43.175924 \\
\hline National Museum of Fine Arts & 1906 & -22.908673 & -43.175712 \\
\hline National Artistic and Historical Heritage Institute & 1908 & -22.900446 & -43.179604 \\
\hline Central Bank of Brazil & 1908 & -22.899690 & -43.180060 \\
\hline Earth Sciences Museum & 1908 & -22.953741 & -43.170353 \\
\hline Gustavo Capanema Palace & 1937 & -22.909540 & -43.173489 \\
\hline
\end{tabular}

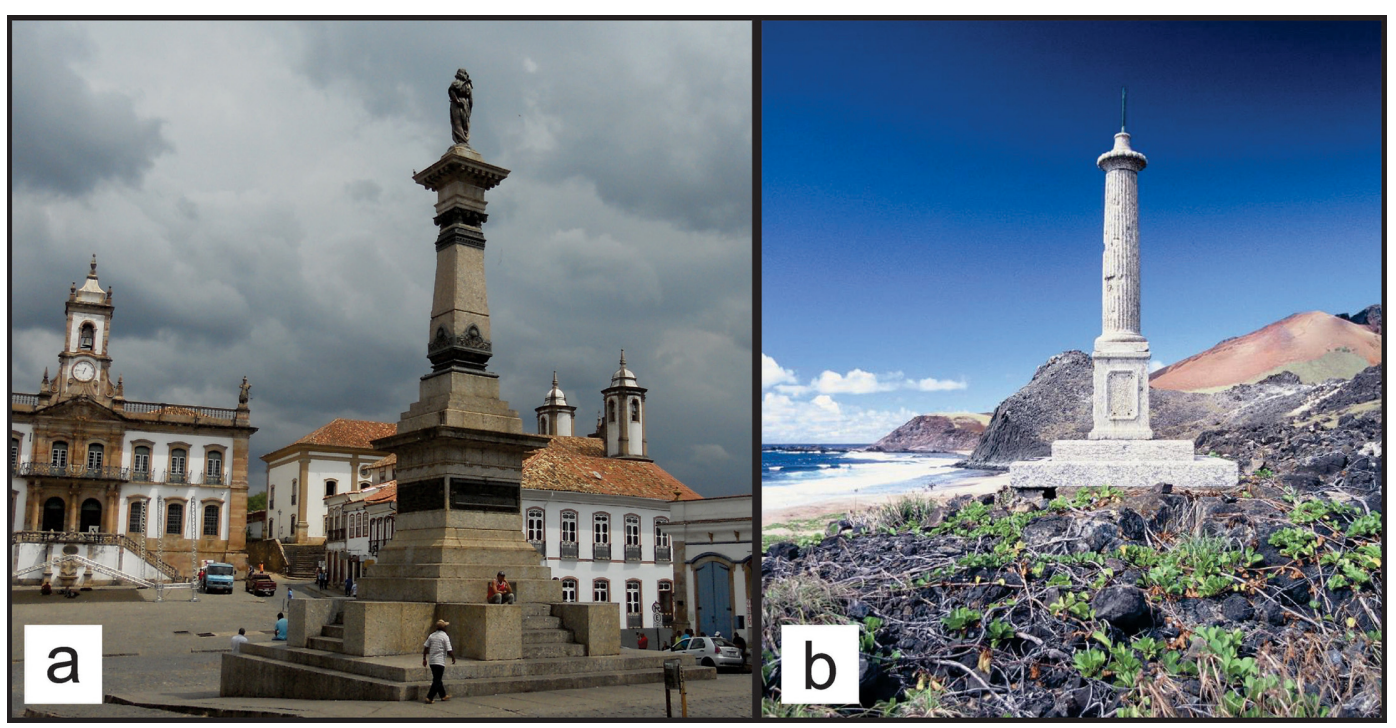

Figure 12. (a) Tiradentes Monument in Ouro Preto, State of Minas Gerais. Photo by the authors, (b) Border landmark in the Trinidad Island, State of Espírito Santo. Photo by PROTRINDADE/PROMAR - SECIRM / Brazilian Navy, used with permission. 
Table 4. Some Brazilian monuments built with Facoidal gneiss

\begin{tabular}{lccc}
\hline \hline \multirow{2}{*}{ Name } & \multirow{2}{*}{ Date of construction } & \multicolumn{2}{c}{ Geographical Coordinates (WGS84) } \\
\cline { 2 - 4 } & & Latitude & Longitude \\
\hline House of Chamber and Jail (São João da Barra, State of Rio de Janeiro) & 1797 & -21.633756 & -41.049737 \\
Visconde de Ipiabas Mausoleum (Valença, State of Rio de Janeiro) & ca. 1886 & -22.242782 & -43.706543 \\
Paulo de Frontin Monument (Valença, State of Rio de Janeiro) & 1917 & -22.247606 & -43.707166 \\
Tiradentes Monument (Ouro Preto, State of Minas Gerais) & 1894 & -20.385379 & -43.503580 \\
Andrada's Border Landmark (Trindade Island, State of Espírito Santo) & 1911 & -20.512924 & -29.307494 \\
Our Lady of Lourdes Statue (João Pessoa, State of Paraiba) & 1922 & -7.115517 & -34.884707 \\
Our Lady of Sorrows Church (Porto Alegre, State of Rio Grande do Sul) & 1876 & -30.030997 & -51.235396 \\
\hline
\end{tabular}

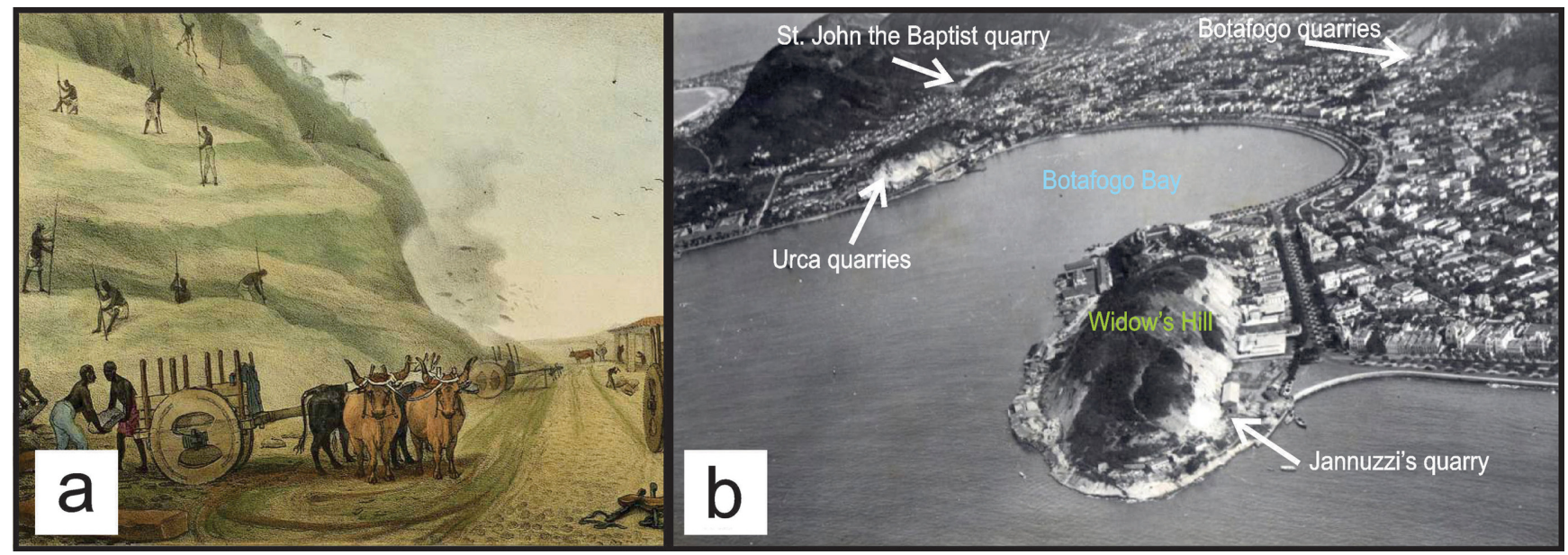

Figure 13. (a) Facoidal gneiss quarrying. Lithograph by Debret, 1834, public domain, (b) Widow's Hill showing Jannuzzi's and other Facoidal gneiss quarries. Photo by the Brazilian Navy, 1922 - RJDPHDM AVNAVAL $1^{a}$ FASE-DE-IC-FAG-47420.

painful work. A Facoidal gneiss quarry lithograph from Debret (1834) is reproduced in Fig. 13a. The Januzzi quarry on the Widow's Hill at Flamengo Beach was one of the most important of the historic quarries (Fig. 13b).

According to Zylberberg (1992), the quarries influenced the slums (favelas) formation in Rio, as the quarry workers occupied the hills above them. At the Providencia Hill (Fig. 3), considered as the first slum of the city, functioned a big Facoidal gneiss quarry.

Notwithstanding the existence of vast reserves, its extraction stopped in the 20th century as the last quarries were closed due to the dense urbanization and environmental protection regulations. Some of those old quarries' scars, though, are accessible to visit adding value to the already existent geotouristic initiatives in the city (https://www.riogeotour.com/).

At the beginning of the 20th century, the municipal codes forbid quarrying close to residences and businesses. However, the latter advanced rapidly occupying the open pathways and areas of the quarries, which lead to their closure. Facing the scarcity of building materials due to the real state pressure for valued regions close to the forested hills, the Engineering General Directorate determined, in 1935, the creation of building materials resources protected areas' as a heritage legacy for future generations (Silva, 1935). It looks that the determination was not respected, but at least nature conservation efforts are, with some struggle, working.

\section{Deterioration and Conservation}

Facoidal gneiss resistance to weathering and low water absorption capacity were known by engineers of the 19th century. Freitas (1878), in his study on the natural stones resources of the city of Rio de Janeiro, gave the example of a church that after around 70 years of exposure maintained 'more or less the natural aspect of the stone.' Today, however, several decay patterns can be observed on Facoidal gneiss in buildings and monuments such as flaking, spalling and material losses, oxidation stains, deposits, loss of matrix (leading to a characteristic protuberance of feldspar crystals over the matrix) and granular disintegration, not to mention the very recurrent graffiti (Fig. 14). Biological action, salts crystallization, and temperature variation are the principal agents of degradation.

Structural features such as faults, joints, and sometimes foliation, control the natural weathering of Facoidal gneiss. The progressive changes are the lustre reduction of feldspars up to opacity, oxidation of garnets and biotite, and exfoliation of the latter by the deposition of iron oxide in between lamellae, up to the loosening of those minerals from the matrix, and fracturing of quartz (Marques et al., 2010).

Accelerated weathering tests performed by Gimenez (2018) showed that even though thermal shock did not visually affect the Facoidal gneiss, water absorption, apparent porosity, and capillary absorption rose $27 \%, 25 \%$ and $94 \%$, respectively. 


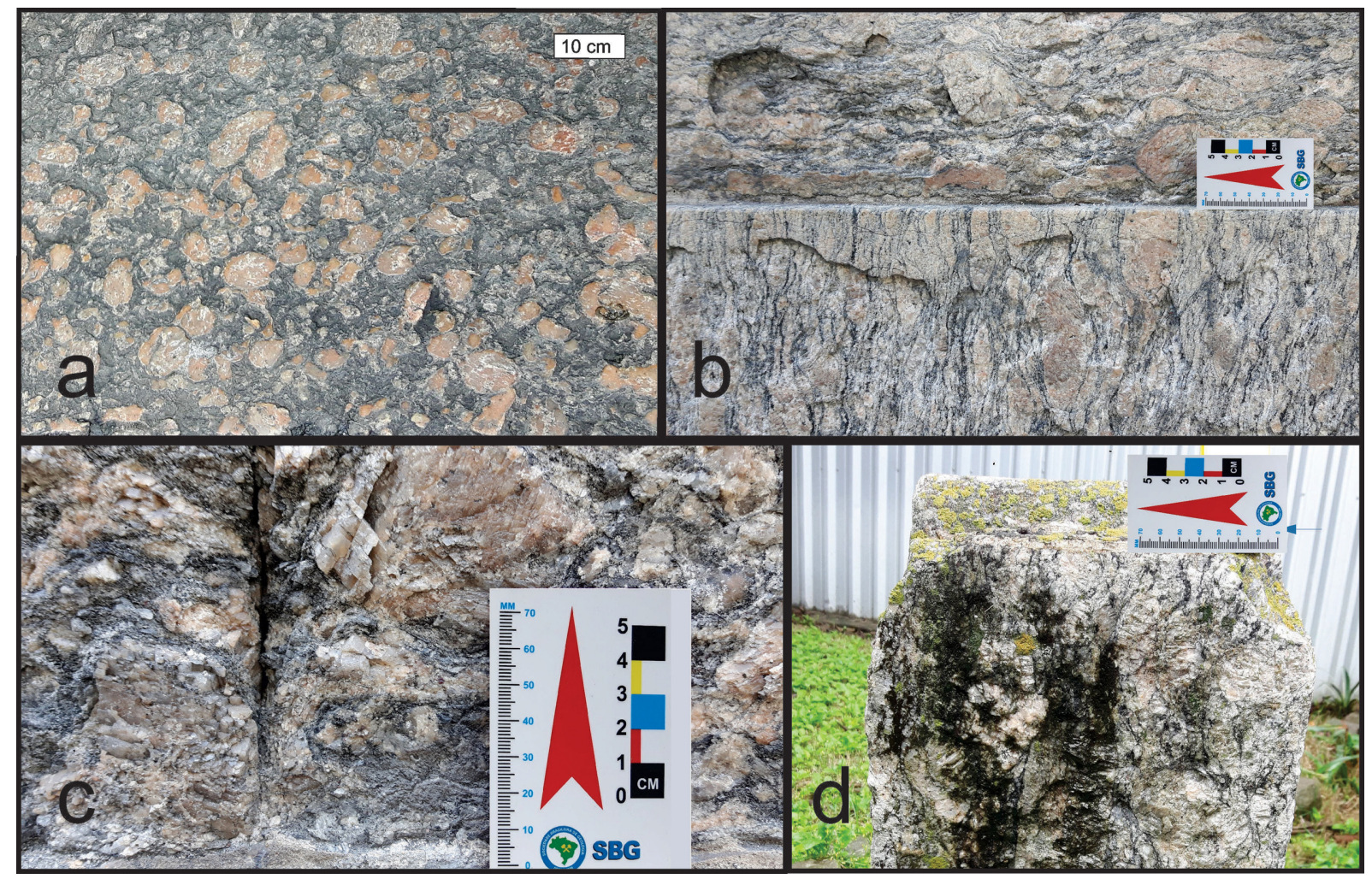

Figure 14. (a) Matrix loss and feldspars protuberance, (b) material loss and spalling, (c) matrix loss and granular disintegration, (d) biological colonization of old stonework in a garden. Photos by the authors.

By its 'city in nature' characteristic, Rio the Janeiro offers diverse environments where some decay agents may be more damaging than others. The historical urban area presents a humid tropical climate, with an average temperature close to $24{ }^{\circ} \mathrm{C}$, relative humidity to $70 \%$, maximum solar radiation of $1,000 \mathrm{~W} / \mathrm{m}^{2}$, and annual precipitation of around 1,000 mm, more concentrated between December and April. Photochemical reactions in Rio's atmosphere are accelerated by high ozone concentration due to solar radiation (PCRJ, 2013).

This coastal and dense urbanized city also has a long tradition of natural conservation. Special attention has been given from the 19th century onwards to the maintenance of biodiversity by replanting and protecting the forested hills and mountains; Rio de Janeiro's natural conservation units comprehend almost $30 \%$ of the municipality territory (PCRJ, 2020). Many landscaped squares, pathways and recreational areas have been built along Rio's history to enhance the quality of the urban space. Consequently, biological action seems to have a significant impact close to forested areas or gardens, producing spalling and granular disintegration (Gaylarde et al., 2018), but some phototrophs found in building stones in those environments, despite their damaging potential, could have a protective action against other decay mechanisms (Ortega-Morales et al., 2019).

Anthropic pollutants (mainly from vehicular emissions) are more significant in the urbanized areas of Rio de Janeiro (Azevedo et al., 1999) and more active in stone decay processes than other present agents, especially in monuments located in narrow canyon-like streets surrounded by high buildings (Baptista Neto et al., 2011).

The crystallization of a mixture of salts, of both natural and anthropic origin, in between biotite lamellae and along the feldspar cleavage planes, increases the anisotropy of the Facoidal gneiss (Ricardo, 2017b), due to the promotion of a fissural network that leads to mineral disaggregation, losing matrix and producing the protrusion of feldspar crystals (Smith et al., 2004). The protrusion of feldspars in Facoidal gneiss is commonly noticeable in pavements and stairs (Fig. 14a). Halite $(\mathrm{NaCl})$ and nitratine $\left(\mathrm{NaNO}_{3}\right)$ seem to be essential players on this gneiss decay. They can be found in monuments inside and outside the more urbanized areas, in quantities varying as a function of the distance to the sea, altitude, and exposure to wind and rain (Smith et al., 2004; Ribeiro et al., 2016; Ricardo et al., 2017a; Gaylarde et al., 2018). Natritine particles of more than $2,5 \mu \mathrm{m}$ can be formed in the atmosphere due to the reaction of gaseous nitric acids over the surface of $\mathrm{NaCl}$ marine spray (Pryor and Sorensen, 2000) or on the stones, as a reaction product of the $\mathrm{NaCl}$ previously deposited and the nitrogen carried by the rain (Smith et al., 2004). The decay is more accentuated in open internal areas, protected from the direct rainwash and sun drying, but exposed to the environment or uprising water (Smith et al., 2004; Ricardo et al., 2017b).

Along with halite, gypsum is also present in many monuments, in higher quantities in dense traffic areas. Gypsum has been identified in cement and mortar leachates incrustations, as well as in superficial crusts that usually detach (Smith and Magee, 1990; Baptista Neto et al., 2011; Ribeiro et al., 2016; Gaylarde et al., 2018). Those crusts also have the contribution of filamentous bacteria and fungi (Gaylarde et al., 2017). A great variety of halophilic and stress-resistant microorganisms, mostly actinobacteria, cyanobacteria and fungi have been identified in stoneworks in Rio de Janeiro (Dourado et al., 2016; Gaylarde et al., 2017b; Gaylarde et al., 2018). Those microorganisms can contribute 
to Facoidal gneiss deterioration by discolouration, organic acids production, and physical action. The yeast Rhodotorula mucilaginosa, a species that could release iron or other cations from the rock structure, has been appointed as a genuine colonizer of this gneiss (Gaylarde et al., 2018).

The best cleaning methods or treatments for stones within Brazilian built heritage have not been adequately studied yet. Stone conservation is performed based on empirical knowledge and restricted to the restoration sites (Andrade, 2016). Despite the ban on quarrying, replacements of Facoidal gneiss, when needed, are possible with demolition material, which is still relatively easy to find. Detachments or small missing pieces are covered with stone repair mortar or imitative paintings, though a new technique mixing coloured mortars has been recently developed, the Stucco Gneiss (Braga, 2020).

\section{Conclusion}

Facoidal gneiss, the porphyroclastic biotite orthogneiss that supports the relief of the Rio de Janeiro's hills and mountains, was the main building stone of that city's urbanization up to the 20th century. It was chosen as the representative stone of the national architecture by past leading architects and engineers and acknowledged as such by Burle Marx, the famous Brazilian landscape architect of the 20th century. Facoidal gneiss reserves are vast but not available for quarrying as they are part of nature conservation units or built over. Additionally, within the built environment, Facoidal gneiss shows signs of decay in the many heritage sites where it is present, mainly by salt crystallization and biological colonization. The processes involved, however, are not well understood yet entangling its conservation. For these reasons, the dissemination of the characteristics of this stone and the promotion of studies to better know its decay processes and responses to conservation practices, as well as the identification of similar and compatible lithotypes for replacement, will enhance the sustainability of this World Heritage Site.

\section{Acknowledgements}

The authors thank the reviewers for their valuable comments and contribution, and Catherine Gallois, from the Institute of National Historical and Artistical Heritage - IPHAN, for sharing some of her knowledge.

\section{References}

Abreu, M., 2010, Geografia Histórica da Cidade do Rio de Janeiro (15021700). v. 1. Rio de Janeiro: Andrea Jakobsson/Prefeitura do Rio de Janeiro.

Almanak Laemmert, 1857; 1859; 1875, Almanak Administrativo, Mercantil e Industrial do Rio de Janeiro. Rio de Janeiro: E. and H. Laemmert.

Almeida, S., and de Almeida, C.M., 2012, "Santa Cruz Fortress: Historical and Geological Heritage of Niterói, RJ, Brazil [Fortaleza de Santa Cruz: Patrimônio Histórico e Geológico de Niterói, RJ].” Anuario Do Instituto de Geociencias v. 35, pp. 222-235. doi:10.11137/2012_1_222_235.

Almeida, S., and Porto Jr, R., 2012, Cantarias e pedreiras históricas do Rio de Janeiro : instrumentos potenciais de divulgação das Ciências Geológicas. Revista Terrae Didatica, v. 8, p. 3-23. doi:10.20396/td.v8i1.8637423

Almeida, S., 2016, Pedreiras, pedreiros, cavouqueiros: personagens esquecidos da história do Rio de Janeiro. In M.F. Vásquez, S. Caponi, and M. R. B. da Silva (Eds.), Anais electrônicos do 15o Seminário Nacional de história da ciência e da tecnologia, $11 \mathrm{p}$.

Alves, T.O.P., 2011, As razões da tradição: o papel do precedente na concepção arquitetônica de Lúcio Costa. Doctoral Thesis. Federal University of Rio Grande do Sul. Architecture. 316 p. https://lume.ufrgs.br/ handle/10183/36817

Andrade, 2016, Francisco de Carvalho Dias de. Uma poetica da tecnica: a producao da arquitetura vernacular no Brasil. recurso online. $276 \mathrm{p}$. Doctoral Thesis - State University of Campinas, Philosophy and HUman Sciences Institute SP. http://www.repositorio.unicamp.br/ handle/REPOSIP/320977. [accessed 31st Mai, 2020]

Azevedo, D., Moreira, L.S., and Soares De Siqueira, D.S., 1999, Composition of extractable organic matter in aerosols from urban areas of Rio de Janeiro city, Brazil. Atmospheric Environment, v. 33, pp. 4987 5001. doi:10.1016/S1352-2310(99)00270-8

Backheuser, E.A., 1925, Breve notícia sobre a geologia do Distrito Federal, Brasil, D. F. Estatística da cidade. Anuário 1923/1924, v. 5, pp. 19-31.

Baptista-Neto, J.A., Smith, B.J., McAllister, J.J., Silva, M.A.M., and Silva, A.L.C., 2011, Salt weathering of historical building stones in Rio de Janeiro central area: a case study of the São Francisco de Paula Church. In: Ioannou, I., Theodoridou, M. (Eds.), Salt Weathering on Buildings and Stone Sculptures. 1, pp. 113-120 Nicosia.

Bell, A.G., 1914, The beautiful Rio de Janeiro. London, Heinemann. in: https://archive.org/details/beautifulriodeja00belluoft/page/n8/mode/2up. [accessed 24th January, 2020]

Braga, M., 2020, Projeto Stucco-Gneisse. http://marciabraga.arq.br/site/ projetos/stucco-gnaisse.html. [accessed 19th January, 2020].

Brazil, 1838; 1855; 1893, Códigos de Posturas do Districto Federal. In: Brasil, 1894, Códigos de Posturas do Districto Federal. Rio de Janeiro. Typ. Montalverne.

Brazil, 2017, Secretaria da Comissão Interministerial para os Recursos do Mar. Protrindade: programa de pesquisas científicas na Ilha da Trindade. 10 anos de pesquisas / SECIRM - Brasília, 2017. 200 p. : il. I S B N: 978-85-62033-03-2.

Burmeister, 1853, Reise nach Brasilien: durch die Provinzen von Rio de Janeiro und Minas Geraës : mit besonderer Rücksickt auf die naturgeschichte der gold-und diamantendistricte. 608p.

Caldcleugh, A., 1825, Travels in South America, During the Years, 181920-21: Containing an Account of the Present State of Brazil, Buenos Ayres, and Chile, Volume 1. London, John Murray.

Carlos Luis M C da Cruz, 2009, (https://commons.wikimedia.org/wiki/ File:Museu_de_ciencias_da_terra.jpg), "Museu de ciencias da terra", marked as public domain, more details on Wikimedia Commons: https://commons.wikimedia.org/wiki/Template:PD-self

Cavalcanti, Nireu, 2004, O Rio de Janeiro setecentista. A vida e a construção da cidade da invasão francesa até a chegada da Corte. Rio de Janeiro, Jorge Zahar Editor, $443 \mathrm{p}$.

CPRM - Serviço Geológico do Brasil, 2020, "GeoSGB.” Accessed September 1, 2020. http://geosgb.cprm.gov.br/.[accessed 27th August, 2020]

Daniel Silva Barbutti, 2017, (https://commons.wikimedia.org/wiki/File:Chafariz_do_Mestre_Valentim.jpg), https://creativecommons.org/licenses/ by-sa/4.0/legalcode

Darwin, C., 1846, Geological Observations on South America. http:// www.gutenberg.org/ebooks/3620_[accessed 10th July, 2020]

Debret, J.B., 1834, Voyage pittoresque et historique au Brésil or, Séjour d'un Artiste Français au Brésil, depuis 1816 jusqu'en 1831 inclusivement, époques de l'Avenement et de l'Abdication de S. M. D. Pedro 1er, fondateur de l'Empire brésilien. Dédié à l'Académie des Beaux-Arts de l'Institut de France, par J. B. Debret.

De Wever, P., Baudin, F., Pereira, D., Cornée, A., Egoroff, G., and Page, 
K., 2017, The Importance of Geosites and Heritage Stones in Cities - a Review. Geoheritage, v. 9, pp. 561-575. doi.org/10.1007/s12371-016-0210-3

Del Vecchio, A., 1884, "Resumo de Experiências Feitas Sobre Os Principaes Granitos Do Rio de Janeiro.” Revista Do Instituto Polytechnico Brazileiro, v. 16, pp. 289.

Edelweiss, F., 1967, Os topônimos indígenas do Rio de Janeiro quinhentista. Revista do Instituto Histórico e Geográfico Brasileiro, v. 275, Rio de Janeiro, pp. 80-134.

Fernandes, N.F., 2010, Rio de Janeiro: A metropolis between granitegneiss massifs. In: Geomorphological Landscapes of the World. [s.l.] Springer Netherlands, pp. 89-100.

Filipo, T., 2014, (https:/commons.wikimedia.org/wiki/File:Interior_da_galeria_dos_canhões.JPG), https://creativecommons.org/licenses/by-sa/ 4.0/legalcode

Freire-Lista, D.M., Fort, R., and Varas-Muriel, M.J., 2015, Alpedrete granite (Spain). A nomination for the "Global Heritage Stone Resource" designation. Episodes, v. 38. pp. 106-113. doi:10.18814/epiiugs/2015/ v38i2/006

Freitas, Antonio de Paula, 1878, "Recursos Da Cidade Do Rio de Janeiro Em Pedras Naturaes e de Construção.” In Revista Do Instituto Polytechnico Brazileiro, 1-15. Rio de Janeiro: Instituto Polytechnico Brazileiro, Ministry of Agriculture, Brazil.

Gaylarde, C., Baptista, Neto, J.A., Ogawa, A., Kowalski, M., CelikkolAydin, S., and Beech, I., 2017a, Epilithic and endolithic microorganisms and deterioration on stone church facades subject to urban pollution in a sub-tropical climate, Biofouling, v. 33, pp. 113-127. doi:10.1080/ 08927014.2016.1269893

Gaylarde, C., Ogawa, A., Beech, I., Kowalski, M., and Baptista-Neto, J.A., 2017b, Analysis of dark crusts on the church of Nossa Senhora do Carmo in Rio de Janeiro, Brazil, using chemical, microscope and metabarcoding microbial identification techniques. International Biodeterioration and Biodegradation, v. 117, pp. 60-67. doi:10.1016/j.ibiod. 2016.11.028

Gaylarde, C., Baptista-Neto, J.A., Tabasco-Novelo, C., and Ortega-Morales, O., 2018, Weathering of granitic gneiss: A geochemical and microbiological study in the polluted sub-tropical city of Rio de Janeiro. Science of the Total Environment, v. 644, pp. 1641-1647. doi:10.1016/j.scitotenv. 2018.07.303

Gardner, G., 1849, Travels to the interior of Brazil. The Linnean Society. http://www.gutenberg.org/ebooks/58045 [accessed 23rd July 2020].

Gimenez, Alexander Martin Silveira, 2018, Suscetibilidade experimental de rochas do patrimônio histórico aos agentes do intemperismo. 2018. 295f. PhD Thesis - Geosciences Institute, University of São Paulo, São Paulo, 2018. doi:10.11606/T.44.2018.tde-10072018-152157

Gonçalves, Aureliano Restier, 2004, Cidade de São Sebastião do Rio de Janeiro terras e fatos. Rio de Janeiro: Arquivo Geral da Cidade do Rio de Janeiro / Divisão de Pesquisa. Available in: <http://www.rio.rj.gov.br/ dlstatic/10112/4204430/4101442/sao_sebast_rj_terras_fatos.pdf $>$. [accessed 11th November, 2019]

Google Earth Pro, 2020, 7.3.2.5776 (64-bit). Rio de Janeiro, Brazil. 22 ${ }^{\circ}$ 55' 33.26" S, 43 07' 41.27" W, Eye alt 20.43 km. Data SIO. NOAA. U.S. Navy. NGA. GEBCO. Terrametrics 2020.

GSL - Geological Society of London, 1829, Transactions of the Geological Society of London. Second Series. Vol. II.

Hall, T.M., 1890, Some North Devon Traps. In: Report and Transactions of The Devonshire Association for the Advancement of Science, Literature and Art. vol. 22. Plymouth: W. Brendon \& Son, p. 235.

Halley Pacheco de Oliveira, 2009, (https://commons.wikimedia.org/wiki/ File:Sítio_Roberto_Burle_Marx_08.jpg), Sítio Roberto Burle Marx 08, https://creativecommons.org/licenses/by-sa/3.0/legalcode

Hartt, C.F., 1870, Geology and Physical Geography of Brazil. London: Fields, Osgood, \& Co.

Hasui, Y., 2012, Geologia do Brasil. 1. ed. São Paulo: Beca-BALL Edições.

Heilbron, M., Eirado, L.G., and do Almeida, J., 2016, Geologia e recursos minerais do Estado do Rio de Janeiro: texto explicativo do mapa geológico e de recursos minerais.: Belo Horizonte: Brasil. Ministério das Minas e
Energia. Serviço Geológico do Brasil - CPRM.

Heilbron, M., Silva, L.G. do E., Almeida, J.C.H. de, Tupinambá, M., Peixoto, C., Valeriano, C. de M., and Girão, R., 2020, Proterozoic to Ordovician geology and tectonic evolution of Rio de Janeiro State, SEBrazil: insights on the central Ribeira Orogen from the new 1:400,000 scale geologic map. Brazilian Journal of Geology, v. 50. doi:10.1590/ 2317-4889202020190099

Hippert, J.F.M., 1990, Contribuição à geologia e petrologia dos "augen" gnaisses de Niterói, RJ. São Paulo, 203p. (Master Thesis) Geoscience Institute, University of São Paulo.

Hughes, T., Lott, G.K., Poultney, M.J., and Cooper, B.J., 2013, Portland stone: a nomination for global heritage stone resource from the United Kingdom. Episodes, v. 36, pp. 221-226.

IBGE - Instituto Brasileiro de Geografia e Estatística, 2020, IBGE | mapas. Retrieved August 31, 2020, from https://mapas.ibge.gov.br/

INEPAC, 2020, Pedra do Sal. http://www.inepac.rj.gov.br/index.php/ bens_tombados/detalhar/20 [accessed 30th August, 2020]

Jardim, Denise Fagundes, 2000, Palestinos no Extremo Sul do Brasil: ldentidade I'Etnica e as Mecanismos Sociais de Producao da Etnicidade - Chui/RS. Rio de Janeiro: UFRJ/PPGAS/Museu Nacional. Doctoral Thesis.

Jonas de Carvalho, 2005, Ilha Fiscal (CC BY-ND 2.0) https://www.flickr.com/ photos/jonasdecarvalho/3777246708/in/faves-187364543@N07/

Lamego, Alberto Ribeiro, 1964, O homem e a Guanabara. Instituto Brasileiro de Geografia e Estatística. 2 ed. 415 p.

Latif, Miran de Barros, 1942, O homem, a casa e a cidade - a Pedra. O Jornal, 20 de junho de 1942 - Ano 1942 Edição 07065 (1).

Lopes, R.J., 2017, 1499, o Brasil antes de Cabral. [s.1.] Harper Collins BR, 248 p, ISBN: 8595080321

Luccock, J., 1820, Notes on Rio de Janeiro and the southern parts of Brazil. Londres: Samuel Leigh, 639 p.

Mansur, K.L., Delphim, C.F.M., Carvalho, I.D.S., and Barroso, E.V., 2008a, O gnaisse facoidal e a cidade do Rio de Janeiro: um caso exemplar de paisagem cultural. Memórias e Notícias, 3 (Nova Série), pp. 469-476.

Mansur, K.L., 2008b, O gnaisse facoidal: A mais carioca das rochas. Anuario do Instituto de Geociencias, v. 31, pp. 9-22.

Marques, E.A.G., Barroso, E.V., Menezes Filho, A.P., and Vargas, E. do A., 2010, "Weathering Zones on Metamorphic Rocks from Rio de Janeiro-Physical, Mineralogical and Geomechanical Characterization.” Engineering Geology v. 111, pp. 1-18. doi:10.1016/j.enggeo.2009.11.001.

Mawe, J., 1812, Travels in the interior of Brazil, : particularly in the gold and diamond districts of that country, by authority of the prince regent of Portugal; including a voyage to the Rio de la Plata, and a historical sketch of the revolution of Buenos-Ayres. London: Longman, Hurst, Rees, Orme And Brown.

Morales de los Ríos, 1911, Mestres, Architectos e Senhorios. O Brazil Artístico. Nova Phase. N. 1. Typographia Leutzinger, Rio de Janeiro, p 212-244.

Morales de los Rios Filho, Adolfo, 1941, Grandjean de Montigny e a evolução da arte brasileira. Rio de Janeiro: A Noite, 1941.

O Globo, 2019, Sítio Burle Marx na briga para ser Patrimônio Mundial Cultural no próximo ano. 08/07/2019 - 04:30 - 07:55. [accessed 20th February, 2020].

Ortega-Morales, O., Montero-Muñoz, J.L., Baptista Neto, J.A., Beech, I. B., Sunner, J., and Gaylarde, C., 2019, Deterioration and microbial colonization of cultural heritage stone buildings in polluted and unpolluted tropical and subtropical climates: A meta-analysis. International Biodeterioration and Biodegradation, 143(July). doi:10.1016/j.ibiod. 2019.104734

PCRJ, 2013, Prefeitura do Rio de Janeiro. Realtório da rede MonitorAr Rio 2011-2102.

PCRJ, 2020, Prefeitura da Cidade do Rio de Janeiro. Unidades de Conservação da natureza.

Pereira, D., Marker, B., Kramar, S., Cooper, B., and Schouenborg, B., (eds). 
2014, Global heritage stone: towards international recognition of Building and ornamental stones. Geological Society, London, special publications, 407 p. doi:10.1144/SP407.13, 261

Pereira, D., Kramar, S., and Cooper, B.J., 2015, Global Heritage Stone Resource: an update. Episodes, v. 38, pp. 78-78.

Porto, J.R., and Duarte, B.P., 2012, Geological evolution of knowledge in the city of Rio de Janeiro (Brazil). In: Para aprender com a Terra: memórias e notícias de Geociências no espaço lusófono. [s.l.] Imprensa da Universidade de Coimbra,. p. 375-382.

Potoko, C.A., 2013, Sant'Anna do Livramento, 1823. BN registro $n^{\circ}$ 532.448 , Livro 1012 - Folha 46.182 p.

Pryor, S.C., and Sørensen, L.L., 2000, Nitric Acid-Sea Salt Reactions: Implications for Nitrogen Deposition to Water Surfaces. Journal of Applied Meteorology, v. 39, pp. 725.

Reis, 1934, As pedreiras do Districto Federal. Revista Municipal de Engenharia\1934\Numero 3 - Volume V - Maio (5).

Retamal, I.B., 2013, Análise e interpretação Petrográfica e Geoquímica para Ortognaisses Facoidais das cidades do Rio de Janeiro e Niterói, RJ. Geosciences Department / Agronomy Institute / Federal University of Rio de Janeiro - UFRRJ. Undergraduate Thesis. Seropédica.

Revista dos Construtores, 1886, http://bndigital.bn.gov.br/acervodigital/[accessed 28th August, 2020]

Ribeiro, R., 2011, Palácio Gustavo Capanema: processo de revitalização e restauração. $9^{\circ}$ seminário docomomo Brasil, Brasília . junho de 2011. www.docomomobsb.org [accessed 5 February, 2020]

Ribeiro, R.C.C., Castro, J.S., Queiroz, J.P.C., and Moura, L.C.R., 2016, avaliação da alterabilidade das rochas da fachada lateral direita do mosteiro de são bento. Geonomos, v. 24, pp. 94-96.

Ricardo, Amanda Menezes, 2015, Uma rocha e um palácio: características e alterabilidade do gnaisse facoidal no Paço Imperial do Rio de Janeiro., 219 f. Master Thesis, Geosciences Institute, Federal University of Rio de Janeiro.

Ricardo, A.M., Barroso, E.V., Mansur, K.L., Vasquez, G.F., and Ribeiro, R. C.C., 2017a, Rock Decay by Salt Crystallization and Seismic Signature. In A. R. M. A. ARMA (Ed.), 51st US Rock Mechanics / Geomechanics Symposium (p. 5). San Francisco, California, USA.

Ricardo, Amanda Menezes, Kátia Leite Mansur, Emilio Velloso Barroso, Fernanda Senra, Gabriela Avellar, and Roberto Carlos da Conceição Ribeiro, 2017b, Mapeamento das morfologias de alteração das rochas do Paço Imperial, Rio de Janeiro. Geologia USP - Serie Cientifica, v. 17, pp. 45-58. doi:10.11606/issn.2316-9095.v17-305

Rodrigo Soldon, 2011, Ilha Fiscal (CC BY-ND 2.0) https://www.flickr.com/photos/soldon/6288515121/in/faves-187364543@N07/

Sá, F., 1886, Materiaes de construção. Revista Philotechnica. Ed. 6. p. 30.

Silva, F.N., 1935, Problemas da cidade. Proteção às jazidas do Districto Federal. Revista Da Directoria de Engenharia Da Prefeitura Do Districto Federal, v. 19, pp. 610-614.

Silva, F.N., 1936, Dados úteis sobre as pedreiras do Districto Federal. Revista Da Directoria de Engenharia Da Prefeitura Do Districto Federal, v. 3, pp. 288-289.

Silva, L.C. da, and Ramos, A.J.L. de A., 2002, Pão de Açúcar, RJ. Cartão postal geológico do Brasil. SIGEP 67. In: Shobbenhaus, C. et al. (Eds.). Sítios geológicos e paleontológicos do Brasil. Brasília: Departamento Nacional da Produção Mineral (DNPM), pp. 263-268.

Silva, L., C. da, and Silva Cunha, H.C., 2001, Geologia do Estado do Rio de Janeiro: texto explicativo do mapa geológico do Estado do Rio de Janeiro. CPRM - Serviço Geológico do Brasil PROGRAMA,pp. 1-88.

Silva, L.C. da, 2003, Zircon U-Pb SHRIMP dating of the Serra dos Órgãos and Rio de Janeiro gneissic granitic suites: implications for the (560 Ma) Brasiliano/Pan-African collage. Ver. Bras. de Geociências. São Paulo. v. 33, pp. 237-244.

Silva, T.M., Ferrari, A.L., Tupinambá, M., and Fernandes, N., 2015, The Guanabara Bay, a Giant Body of Water Surrounded by Mountains in the Rio de Janeiro Metropolitan Area. In R. P. Maia \& F. H. R. Bezerra (Eds.), Landscapes and Landforms of Brazil, 268 p. doi:10.1007/97894-017-8023-0

Schmitt, R.S., Fragoso, R.A., and Collins, A.S., 2018, Suturing Gondwana in the Cambrian: The Orogenic Events of the Final Amalgamation. In: Siegesmund S., Basei M., Oyhantçabal P., Oriolo S. (eds) Geology of Southwest Gondwana. Regional Geology Reviews. Springer, doi:10.1007/ 978-3-319-68920-3 15

Smith, B.J., Baptista-Neto, J.A., Silva, M.A.M., McAlister, J.J., Warke, P.A., and Curran, J.M., 2004, The decay of coastal forts in Southeast Brazil and its implications for the conservation of colonial built heritage, v. 46, pp. 493-503. doi:10.1007/s00254-004-1051-y

Smith, B.J., and Magee, R.W., 1990, Granite weathering in an urban environment: an example from Rio de Janeiro. Singapore journal of tropical geography, v. 11, pp. 143-153. doi:10.1111/sjtg.1990.11.issue-2

Smith, B.J., Baptista Neto, J.A., Silva, M.A.M., Warke, P.A., McAlister, J.J., and Curran, J.M., 2004, Conservation of colonial built heritage: practical considerations and cultural constraints in Rio de Janeiro. Environmental Geology, v. 46, pp. 493-503.

Spix, J.B., and Martius, C.F.P., 1824-1831, Travels in Brazil in the years 1817-1820, undertaken by command of His Majesty, the King of Bavaria. Three volumes and one Reise atlas of illustrations. London: Longman, Hurst, Rees, Orme, Brown and Green.

Swann, L., 2018, Discovering geological stories in every postcode through online self-guided fieldtrips: an example of small Geotourism. Australian Institute of Geoscientists. GPIC Technical Meeting, Victoria, August 2018. https://www.leisuresolutions.com.au/presentations/[accessed 12th October, 2019]

Telles, Augusto Carlos da Silva, 2007, Atlas dos Monumentos Históricos e Artísticos do Brasil. Monumenta. Brasília: IPHAN, 2007.

Tupinambá, M., Teixeira, W., and Heilbron, M., 2012, Evolução Tectônica e Magmática da Faixa Ribeira entre o Neoproterozoico e o Paleozoico Inferior na Região Serrana do Estado do Rio de Janeiro, Brasil. An. do Instituto de Geociencias, v. 35, pp. 140-151.

UNESCO, 2012, Rio de Janeiro: Carioca Landscapes between the Mountain and the Sea https://whc.unesco.org/en/list/1100 [accessed 15th February, 2020]

UNESCO, 2017, The outstanding universal value of the « Valongo Wharf Archaeological Site /United Nations Educational, Scientific and Cultural Organization. http:/www.unesco.org/new/en/media-services/singleview/news/the_outstanding_universal_value_of_the_valongo_wharf_arch/ [accessed $12^{\text {th }}$ January, 2020]

United States. Census Office, 1880, 10th census. Special Reports on Petroleum, Coke, and Building Stones, v. 3.

Valeriano, C., 2012, Geologia e recursos minerais da folha Baía de Guanabara SF.23-Z-B-IV, estado do Rio de Janeiro escala 1:100.000. Belo Horizonte: CPRM, 2012.

Von Gnielinski, F., and Siemon, J., 2012, Self-guided Walking Tour featuring Building Stones through Brisbane CBD. 34th International Geological Congress. $14 \mathrm{p}$.

Vonier, T., 2019, Rio de Janeiro: mountains, sea... and architecture - UNESCO World Heritage Centre. (2019, February 19). http://whc.unesco.org/en/ news/1955/ World capital architecture.

Zylberberg, Sonia (coord.). 1992, Morro da Providência: memórias da "favella". Prefeitura do Rio de Janeiro, Secr. Municipal de Cultura, Turismo e Esportes. 


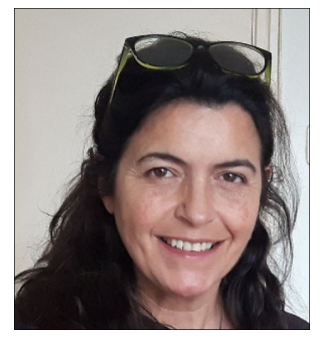

Nuria F. Castro is a Geology $\mathrm{PhD}$ student at the Federal University of Rio de Janeiro UFRJ, researching on Natural Stones Conservation, whilst works at the Centre for Mineral Technology - CETEM/MCTI, as Senior Technologist. She was born in Spain where she studied Mining Engineering, at the School of Mines of Madrid in 1994. Since then has been living in Brazil, obtaining an MSc and two Specializations in Geology. She was Head of CETEM's Natural Stones Branch in the State of Espirito Santo $(2009$ - 2018). She has experience in Mineral Clusters, Sustainable Development, Natural Stones Quarrying and Processing and Scientific Dissemination.

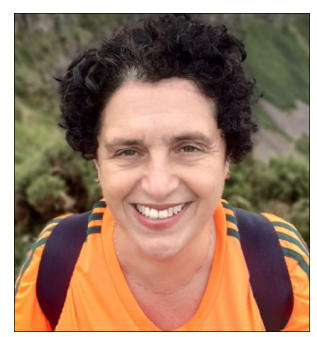

Dr Kátia Leite Mansur is a professor at the Geosciences Institute of the Federal University of Rio de Janeiro - UFRJ, with experience in Geoconservation, Science popularisation, Environmental Geology, and Hydrogeology. Kátia worked for 29 years at the Geological Survey of the State of Rio de Janeiro - DRM$\mathrm{RJ}$ - coordinating the project 'Geological Paths.' She coordinates the Darwin Paths Project and the Management Group of the Geopark Cliffs and Lagoons of the State of Rio de Janeiro Project. She is the Director of the Geodiversity Museum/UFRJ and received an award from the Brazilian Geological Society by her contribution to Geology's popularisation.

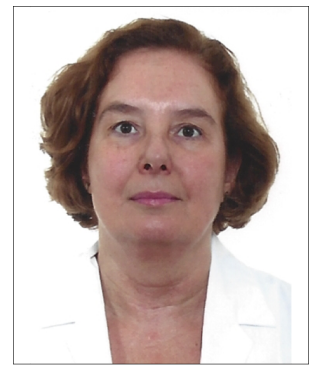

Dr Maria Heloisa Barros de Oliveira Frascá is presently an independent consultant at MHB Geological Services, São Paulo, Brazil, acting in engineering geology, including studies on deterioration and conservation of rocks. MSc and $\mathrm{PhD}$ degrees were obtained at the Institute of Geosciences of the University of São Paulo, Brazil. Previously, was a researcher at IPT - Institute for Technological Research of São Paulo State (1981 to 2012), coordinating multiple projects and studies on natural stones and aggregates. She is member of editorial boards and reviewer of national and international journals, and vice-chair (20172020) of the Subcommission on Heritage Stone of the International Union of Geological Sciences (IUGS).

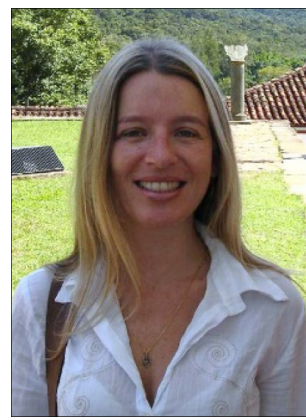

Dr Rosana Elisa Coppedê Silva is a researcher on Natural Stones Conservation at the Centre for Mineral Technology - CETEM/MCTI. MSc (1997-1999) and PhD (2000-2005) degrees were obtained at the Institute of Geosciences of the Federal University of Rio de Janeiro, Brazil. Previously, she worked with natural stones in the States of Espírito Santo (19951996) and Rio de Janeiro (1997-1999), and in Italy (2002). She has experience in mineral and environmental legislation, mineralogy, regional geology, hydrogeology, geotechnics and relationships with public licensing agencies. 